\title{
Entrepreneurial performance of New Generation Rural Migrant Entrepreneurs in China
}

\section{Abstract}

\section{Purpose}

China has a new rural revitalization strategy to stimulate rural transformation through modernizing rural areas and resolving their social contradictions. While social capital is recognized as an important element to rural revitalization and entrepreneurship, research into the role of psychological capital is less developed. Therefore, this paper assesses the impact of both social and psychological capital on entrepreneurial performance of Chinese new-generation rural migrant entrepreneurs who have returned to their homes to develop businesses as part of the rural revitalization revolution.

\section{Design/methodology/approach}

Based on a survey, data was collected from 525 new generation rural migrant entrepreneurs in Shaanxi Province. This paper uses factor analysis to determine variables for a multiple linear regression model to investigate the impacts of dimensions of both social and psychological capital on new-generation rural migrant entrepreneurs' entrepreneurial performance.

\section{Findings}

Through the factor analysis, social capital of these entrepreneurs consists of five dimensions (reputation, participation, networks, trust, and support); psychological capital has three dimensions (innovation and risk-taking, self-efficacy, and entrepreneurial happiness), while entrepreneurial performance contains four dimensions (financial, customer, learning and growth, and internal business process). Furthermore, the multiple linear regression model empirically verifies that both social and psychological capital significantly influence and positively correlate with new generation rural migrant entrepreneurs' entrepreneurial performance.

\section{Originality/value}

This study shows the importance of how a mixture of interrelated of social and psychological dimensions influence entrepreneurial performance that may contribute to the success of the Chinese rural revitalization strategy. This has serious implications when attempting to improve the lives of over 100 million rural Chinese citizens. 


\section{Introduction}

China's new rural revitalization strategy attempts to stimulate rural transformation through modernizing rural areas and resolving their social contradictions (Liu, 2018; Wang and Zhuo, 2018; Zhou et al., 2020). In 1978, China's rural economic reform exacerbated the problems of social contradictions resulting in an unprecedented movement of rural workers to cities ( $\mathrm{Li}$ et al., 2018). Thus between 1978 and 2017, the population of urban areas increased from 172 million to over 813 million, while rural population showed a significant decrease from $82.1 \%$ to $41.5 \%$ of the total population (Qi et al., 2019). By 2017, the total number of rural workers who worked in large cities in China had increased to around 286 million (Liu and Li, 2017).

The economic drivers that created opportunities in urban areas included market-led reform, economic globalization and land-economic-led urbanization (Gu et al., 2017; Hao, 2012). At a personal level, rural migrants are often attracted to urban centres as they are striving for a better life, which enables them to send money back to their families (Murphy, 2002; Zhao et al., 2018). However, rural outward-migration impoverishes small villages and rural communities as it drains their populations, separates families as parents leave their children behind, which in turn, leads to social issues and a general 'hollowing out' of rural areas (Li, 2004; Liu, 2018; Wei, 2018). To address this, part of the Chinese government's policy of 'rural revitalization' is to support the return of rural workers back to their home areas to set up businesses that stimulate rural endogenous development (Démurger and Xu, 2011; Li, 2019; Zhou et al., 2020). As entrepreneurs they apply to their new businesses the knowledge, skills, and experience that they have acquired from their work in the city. According to Liu and Li (2019), the 'rural revitalization' strategy is expected to revolutionize the traditional rural economic growth model, generate new business forms and models, adjust the rural industrial structures, and revitalize rural areas. These changes should reduce absolute poverty and drive rural 
development. At a personal level, migrants' entrepreneurship may create new businesses and enhance their own personal happiness (Yuan et al., 2019).

The generation born in China in the 1980s and 1990s, who moved from rural areas to live and work in cities, are defined as 'New generation rural migrant workers' (NGRMWs) (China State Council, 2010; Wang, 2000). This definition describes a group of people who have a unique cultural background and identity ( $\mathrm{Li}$ and Chen, 2016) and accounts for around 100 million Chinese citizens (Chinese National Bureau of Statistics, 2009). Different from the old and traditional rural workers, these new-generation rural workers are not familiar with farming but instead desire to be part of city life (Chen and Hu, 2016; Lenton and Lu, 2016; Li and Huo, 2016). Zhang and Song (2003) argue that wider economic incentives for growth attracts these rural workers to cities as they migrate in search of long-term economic benefits. Characteristically, NGRMWs are described as being 18 to 25 years old, more educated with higher career aspirations, demand greater material and spiritual enjoyment but have a lower tolerance for hard work (Wang et al., 2010). This research considers entrepreneurs in their first few years of entrepreneurship that were once NGRMWs. For brevity, these are termed New Generation Rural Migrant Entrepreneurs (NGRMEs). This captures former workers that have returned to their hometowns to develop new businesses as part of the rural revitalization revolution. Indeed, it is estimated that more than two million rural migrants (based on Chinese Ministry of Agriculture statistics) have returned to their hometown since 2016 to pursue this specific purpose (Liu, 2018b). The majority of these were younger people. There are multiple reasons why migrants choose to return (Duan et al., 2019; Tang and Hao, 2019). These include life-changing opportunities, lifestyle preferences to family obligations, increases in urban living costs, restricted access to government welfare and services, cultural factors, and government rural revitalization and support policies (Simmons and Cardona, 1972; Gmelch, 1980; Constant and Massey, 2002; Brauw and Rozelle, 2008; Tang and Hao, 2019). 
Furthermore, new rural businesses created by NGRMEs may moderate problems such as 'hollow' rural areas as they support rural revitalization and upgrade an area's industrial structure (Démurger and Xu, 2011).

It is recognized that NGRMEs also encounter resource difficulties when starting a business such as capital shortage, low knowledge levels, and lack of business experience (Gao and Zhang, 2014). A contributory factor may also be a low level of entrepreneurial performance (Zhuang et al., 2015). Yet effective use of intangible capitals, such as social and psychological capital, may be the key to achieving better entrepreneurial performance (Munshi, 2004; Schwarz, 2017). Social capital is obtained through relational networks and interpersonal communications (Munshi, 2004). In such a 'relational' society, social capital has a significant impact on people's socioeconomic status. The various resources that people obtain through social capital can affect all aspects of their economic life (Fei, 2009). Furthermore, social capital is recognized as an important element to rural revitalization and entrepreneurship ( $\mathrm{Li}$, 2019; Wu et al., 2019). Compared with the traditional migrant workers, the NGRMEs have greater diversity in their social capital: more friends and higher heterogeneity within their social networks (Wang et al., 2011).

Psychological capital draws from positive psychology and positive organizational behaviour (Luthans and Youssef-Morgan, 2017). Furthermore, its attributes have the potential to make a positive impact on an individual's work attitude, behaviour motivation and work performance (Avey at al., 2010). It is also thought to be significant to entrepreneurial behaviour (Bockorny and Youssef-Morgan, 2019; Hmieleski and Carr, 2008; Jensen and Luthans, 2006). However, Chinese NGRMEs are susceptible to frustration when encountering business and work setbacks due to a relatively low level of education and social experiences (Wang et al., 2011). In addition, being away from their hometown and established social networks can lead to a loss 
in their social capital. It is possible that their entrepreneurial phenomenon may be a result of clustering entrepreneurship (Wang et al., 2011; Wu et al., 2019). Yet entrepreneurs who were NGRMEs, as compared to traditional migrant workers, are more capable of psychological endurance and are more innovative (Wu et al., 2019).

Despite these observations, few studies have investigated initiatives that influence new entrepreneurs and their entrepreneurial performance from the dual perspectives of social and psychological capital. Crucially, the success of this form of rural development partly relies on the levels of these types of capital that returning workers have acquired while in the cities. Furthermore, they need the ability to deploy these to create successful entrepreneurial businesses (Zhong and Huang, 2012). Therefore, it is pertinent to explore what factors influence the entrepreneurial performance of NGRMEs.

The resource-based theory (RBT) explains the link between resource-based relatedness and firm-level performance, whilst emphasizing the importance of maintaining firms' existing knowledge base and capabilities to achieve the business growth (Penrose, 1959). Barney (1991) applied the resource-based theory by classifying the strategic resource attributes that generate the firms' sustainable competitive advantage, and ultimately, he highlighted that creativity, entrepreneurial spirit, resources and its allocation and development are the keys for firms to obtain excess profits and maintain their competitive advantages. The social and psychological capital of NGRMEs are such unique resources that they affect entrepreneurial performance once they become entrepreneurs. Based on the Balanced Scorecard (BSC) theory (Kaplan and Norton, 1992), traditional financial models can merely measure past events (lagging outcome factors), but they are not able to assess the company's forward-looking investments (leading driving factors). Hence, Kaplan and Norton (1992) established a new type of performance management system using measurement indicators based on financial, customer, learning and 
growth and internal business process indexes. In this research, entrepreneurial performance of new entrepreneurs is measured by the financial, customer, learning and growth and internal business process indexes.

This paper analyzes the impact of social and psychological capital on entrepreneurial performance of entrepreneurs of NGRMEs based on a survey of 525 participants in the Shannxi Province of China. It also explores how these capitals contribute to their entrepreneurial development. The paper starts by defining the key concepts, proposes research hypotheses, and constructs a theoretical research framework, followed by an introduction to the data sources, variables, and measurement models. Based on factor analysis and multiple linear regression, the paper verifies the research hypotheses before discussing and concluding with the key findings.

This paper is answering the call from Dias et al. (2019) who argues that more studies are needed to better understand entrepreneurial strategies and the processes that orientate them to enable entrepreneurial action. Furthermore, a rise in research into Chinese entrepreneurship has brought to the forefront the importance of contextualizing entrepreneurship and how they are shaped and shape the contexts they live and operate (Baker and Welter, 2020). In particular, Baluku et al. (2018) calls for further understanding of how relational networks and psychological capital specifically contribute to different aspects of entrepreneurial success and how these support new entrepreneurs.

The major contribution of this paper is therefore threefold. Firstly, to advance the existing body of literature on NGRMEs and especially the research conducted by Liu (2018a) which is focused on individual or organizational performance as well as Ke et al.'s (2010) which finds that social and especially psychological capital have a positive correlation between task and peripheral performance. Secondly, to provide a theoretical contribution in the division of the 
dimensions in entrepreneurial performance of NGRMEs and the proposal of a theoretical framework that indicate the impact that social capital and psychological capital have on their entrepreneurial performance. And thirdly, to explore what factors and mechanisms affect the entrepreneurial performance of NGRMEs from the perspective of their social capital and psychological capital. The findings will be conducive to break through the bottleneck that limits improvement in their entrepreneurial performance in the Chinese context. Furthermore, the results of the paper may make suggestions to the relevant government departments when formulating policies to encourage entrepreneurship from the perspective of the endogenous resources of NGRMEs to improve their entrepreneurial performance and promote rural revitalization through their entrepreneurship.

\section{Theoretical Framework}

\subsection{Concepts definition}

\subsubsection{Social capital of the NGRMEs}

With the continuous development of China's economy and society, an increasing number of people pay greater attention to the intangible capital such as social capital and psychological capital (Luthans et al., 2005; Schwarz, 2017). Putman (2000) attributes the term 'social capital' to L. J. Hanifan, a practical reformer in the Progress Era, but argues that Hanfan's writing in 1916 was limited. In the 1970s, Bourdieu and Passeron (1977) establish that social capital and social networks are closely integrated. As an intangible resource, social capital is obtained through relational networks and interpersonal communications (Munshi, 2004). Portes (1998) agrees to Bourdieu and Passeron (1977) and Munshi (2004) by claiming that social networks play an important role in social capital, as social members can gain scarce resources through social networks. However, Burt (2009) argues that social capital was not only a social resource but also a social structure that can provide its members greater opportunities for development. 
There is an array of measures of social capital. Coleman (1988) proposes that social capital consists of five dimensions: social organization, information networks, obligations and expectations, authority relations, norms and effective punishment. Sabatini (2009) measures social capital from four dimensions: informal relations, strong family relationships, political participation and voluntary organizations. Silva et al. (2007) expands on these suggesting eight main dimensions: community belonging, trust, social cohesion, participation in community, social support, social networks, family social capital, and participation in public affairs. However, Narayan and Cassidy (2001) measure social capital using participation in organizations, living in harmony, general societal norms, neighbourhood links, trust measurement, daily contacts, and volunteerism. Trust is also important to Pei (2010), who identifies six dimensions of social capital including standard trust, general trust, informal networks, formal networks, common vision and social support. The most extensive measure however is by Zou and Huang (2014) suggesting 29 factors in seven dimensions such as social belonging, local social networks, non-local social contacts, community cohesion, reciprocity and general trust, and community trust. The importance of social networks is elaborated by Zhou et al. (2013) who measure them from three perspectives. First, their size, differences, composition, and index of social networks are measured to distinguish between stocks and flow. Second, measuring the expenditure of migrant workers on Chinese New Year greetings in Beijing and in their hometown. Third, measuring the emotional and instrumental social networks of migrant workers in Beijing to distinguish the investment in and role of social capital.

Yang (2012) also measures social capital but through four different indicators: social trust, social networks, social reputation, and social participation. The specific indicators as measures of social trust and social networks respectively include the level of trust and mutual assistance from family members, relatives, neighbours, agricultural organizations, village 
committees and village cadres. However, Guo and Zhou (2013) argue that indicators of social networks are mainly based on their size and intensity. Network size may be a measure of the number of friends, relatives and other people of close contact during the Spring Festival, whereas the network intensity may be measured by the frequency of contact, the degree of support and trust. In terms of social reputation, these measures may also include the frequency of being invited to help others and to participate in decision-making, as well as the degree of respect (Yang, 2012). Finally, measures for social participation consist of frequency of participation in democratic elections, making decisions on public affairs and organizing group activities (ibid.). Given the different measures of NGRMEs' social capital, a combination of indicators from Yang (2012) and Guo and Zhou (2013) are adopted with specific characteristics focused on the number of relatives of frequent contact, entrepreneurship supported by friends and relatives, access to labour, strong cohesion in the community, and close contact with potential or existing business partners. Hence, this draws on the research to measure the social capital of the NGRMEs from the five dimensions: social reputation, social participation, social networks, social trust and social support.

\subsubsection{Psychological capital of NGRMEs}

Psychological capital is the psychological potential that has a positive impact on individual's work attitude, behaviour motivation and work performance (Avey et al., 2010). The term 'psychological capital' was first proposed by Luthans et al. (2004), and has become a central psychological element of an individual's general positivity (Luthans et al., 2007a). Early research on entrepreneurship tended to focus on analysing entrepreneurial behaviour through classic economic models that neglected individual psychological differences and failed to explain the disparities in entrepreneurial outcomes (Obschonka, 2017). 
An expansive set of elements that describe psychological capital include wisdom, sense of happiness, experience, creativity, gratitude, forgiveness, humour, courage, emotional intelligence and spirituality (Luthans and Youssef et al., 2004). Avolio (2005) further deepens the concept suggesting that psychological capital was not only a positive psychological state but also includes four constituent dimensions of hope, optimism, self-efficacy and resilience. As such, psychological capital shows that people have persistence to achieve targets and have optimistic expectations about the future. Furthermore, these four constituent dimensions are important in studies examining entrepreneurial psychological capital (Luthans et al., 2005; Luthans and Ibrayeva, 2006; Luthans et al., 2007b).

Common measurement tools for psychological capital include the Psychological Capital Scale (Luthans et al., 2005), the Psychological Capital Questionnaire (PCQ) (Luthans et al., 2007a), and the scale of psychological capital developed by Chinese scholars (Ke et al., 2010; Wu et al., 2012; Xiao and Li, 2010). In the context of Chinese research, Ke et al. (2010) developed a scale of psychological capital to measure it from transactional and interpersonal dimensions. Transactional dimensions include measurement indicators such as confidence, courage, optimism and hope, whereas interpersonal dimension includes localized indicators such as gratitude and forgiveness. This was partly based on Avolio's (2005) questionnaire to measure psychological capital with scales for self-efficacy, resilience, hope and optimism. Alternatively, Zhang et al. (2008) propose that psychological capital should be measured by five aspects: adventurous tendency, internal control characteristics, self-efficacy, innovation and need of achievement. The belief is that NGRMEs hold a positive psychological state when starting a business. Therefore, this paper measures the psychological capital of NGRMEs by focusing on innovation, risk-taking tendency, self-efficacy and entrepreneurial happiness.

\subsubsection{Entrepreneurial performance of the NGRMEs}


NGRMEs in this research refer to those rural entrepreneurs who are engaged with businesses activities such as planting and breeding, wholesaling, retailing and processing, etc. (Ma, 2016). There are different ways in which entrepreneurial performance might be measured. For instance, Borman and Motowidlo (1993) suggest that it should be measured by two dimensions: task performance and peripheral performance. Whereas Chrisman, Bauerschmidt and Hofer (1998) cite two different dimensions to measure psychological capital: survival and growth. A further way to measure entrepreneurial performance is by calculating the proportion of expenditure on housing construction and education that is relevant to annual net entrepreneurial income (Huang and Zou, 2014).

In considering the characteristics of entrepreneurial migrant workers, such as securing a basic livelihood, pursuing profits, and being relatively sensitive to income, Zhu (2010) measures annual entrepreneurial income to indicate their entrepreneurial performance. In contrast, farmers in China, are characterized as satisfying the needs of their life, improving their living conditions, adapting to their external environment, and maximizing their benefits. As such, Sun et al. (2010) suggest that entrepreneurial performance has four aspects: social influence, employment, personal satisfaction, and profit. Zhou and Xie (2012) claim that the main purpose of farmers' entrepreneurship is to increase incomes to improve the industrial structure in rural areas. Therefore, the entrepreneurial performance may be measured through the number of workers employed and the household income in the corresponding year.

Chinese entrepreneurship is based more on a physiological and safety needs rather than higher level needs (Taormina and Kin, 2007). Therefore, research on personal entrepreneurial performance, including personal income and quality of life, appears to be rather meaningful. As a result, this paper adopts the measures of NGRMEs' entrepreneurial performance from four dimensions as suggested by Ma (2016): financial performance that prioritizes income, 
quality of life and entrepreneurial goal achievement; customer performance that concerns scale of entrepreneurship, market share and overall operations; learning and growth performance that focuses on self-worth, abilities, contribution to society; and performance of internal business process that concentrates on innovation.

\subsection{Hypothesis development}

\subsubsection{Social capital and the entrepreneurial performance of the NGRMEs}

Social capital of entrepreneurs is formed and shaped by constant interaction with others and this influences their economic activities (Liu, 2018a). Woodward (1988) claims that social capital plays a significant role in entrepreneurship, while Aldrich and Zimmer (1986) incorporate social capital theory into their entrepreneurship research.

In China, blood, kinship, and geographical relationship are the basic bonds of social structure (Fei, 2009), which profoundly affects individual living circumstances and social status. In Chinese rural areas, these properties create the 'acquaintance society' in which social networks are critical to the life of the local society (Fan \& Zhou, 2013). In addition, social networks also influence individual's economic behaviour and resource acquisition (Guo \& Yao, 2013). It is found that the acquisition of resources in social capital can moderate entrepreneurial risk of NGMRWs (Zhou, 2013). Social capital accumulated from the family can provide direct resource support for entrepreneurs, thereby reducing the difficulty of starting a business (Ma et al., 2019). An entrepreneur's individual experience has a significant impact on their entrepreneurial behaviour. The more experience that he or she has, the more entrepreneurial opportunities are likely to occur (Yang, 2011). Therefore, social network indicators such as the size of an entrepreneur's network of friends and relatives, the number of frequently connected friends, and monthly telephone bills are significant to entrepreneurial behaviour and performance (Zhu, 2010, Ding and Guo, 2013a). 
Characteristics of social networks may influence entrepreneurial performance, particularly if they are heterogeneous (Senjem and Reed, 2002; Liu, 2013; Xie et al., 2016). However, Wang et al. (2010) propose that homogeneous social networks are more conducive to the entrepreneurship of NGRMEs as self-similar networks are more likely to motivate their entrepreneurial behaviour. Zhang (2015) considers that there are significant positive correlations between the number of friends and relatives serving as civil servants, working in cities, the harmony with local people and the willingness of the NGRMEs to start their own businesses. Concordantly, Zhang et al. (2015b) suggest a significant positive correlation between the social network of the NGRMEs and their entrepreneurial intentions. Indeed, strong local network ties may have more influence on entrepreneurial performance (Huang et al., 2010). In summary, network intensity has a positively significant impact on individual and entrepreneurial performance. The more frequent the contacts between an entrepreneur and his or her network members, the more mutual trust and support is garnered (Ding and Guo, 2013a). Consequently, the dimensions of social capital such as social reputation, social participation, social network, social trust and social support may have an impact on entrepreneurial performance, particularly on financial performance, customer performance, learning and growth performance and performance of internal business process. Therefore, the following research hypothesis is developed: Five dimensions of social capital have a positive impact on the four dimensions of entrepreneurial performance of the NGRMEs.

\subsubsection{Psychological capital and the entrepreneurial performance of the NGRMEs}

Psychological capital promotes individual growth (Luthans et al., 2007b; Li, 2012; Ren et al., 2013; Hu, 2015) and is shown to relate to performance (Avey et al., 2010; Walumbwa et al., 2010). Avey et al. (2006) suggest that employees with positive psychological capital have stronger willingness to organizational commitment and to improve peripheral performance. 
Furthermore, it can raise the profitability and performance level of an organization (Luthans et al., 2005, Luthans et al., 2007b) as well as having a significant positive impact on entrepreneurial performance (Cheng, 2015).

The entrepreneurial process is an effective application of psychological capital, thereby improving the entrepreneurship success rate and quality. Therein, self-efficacy and hope are two dimensions of psychological capital that have a significant impact on the quality of entrepreneurship, although optimism and resilience are not decisive factors for entrepreneurial success in the early stages, they are important in promoting long-term entrepreneurial performance (Chen et al., 2019; Şahin et al., 2019). In studies, self-efficacy is shown to be closely related to individual performance (Stajkovic and Luthans 2003; Wang and Fan, 2004). Luthans and Ibrayeva (2006) verify that self-efficacy of entrepreneurs played a direct and regulatory role in entrepreneurial performance. Luo et al. (2009) further clarify the significant positive correlation between entrepreneurial efficacy and entrepreneurial performance. In addition, Avey et al. (2006) suggest that there is a positive correlation between self-efficacy and organizational commitment and periphery performance. Stajkovic and Luthans (1998) suggest that employee' self-efficacy can increase the impact of external factors connected to job performance. In particular, it can have a positive and significant effect while employees with optimistic psychological capital are more likely to achieve high job performance (Seligman and Schulman, 1986). Duan et al. (2015) advocate that a general sense of selfefficacy of NGRMEs can result in a positive impact on their entrepreneurial efficacy and entrepreneurial intentions. In the same entrepreneurial environment, people with high entrepreneurial self-efficacy are more sensitive to business opportunities than those with low entrepreneurial self-efficacy. Therefore, entrepreneurial self-efficacy is an important factor affecting the entrepreneurial performance of NGRMEs (Weng et al., 2019). Risk taking is 
commonly viewed as one of the reasons for entrepreneurs to achieve success (Han and Gao, 2018; Lou et al., 2012; Brändle et al., 2019). Covin and Slevin (1991) believe that both innovation and risk-taking have a positive impact on entrepreneurial performance. Innovation has a positive impact on business performance, as businesses with innovation tend to perceive market changes faster than those without (Zhang et al., 2015c). The role of innovation may act as an effective predictive indicator of performance (Ding and Guo, 2013a, 2013b) although self-efficacy may also play a role (Wang and Fan, 2004). Furthermore, NGRMEs with strong psychological capital demonstrate more entrepreneurial skills at a higher performance level (Li, 2012), as they have better career prospects and can raise individual social capital (Chen, 2013).

As a result, dimensions of psychological capital such as innovation and risk-taking tendency, self-efficacy and entrepreneurial happiness may have an impact on the dimensions of entrepreneurial performance such as financial performance, customer performance, learning and growth performance and performance of internal business process ).Therefore, the second hypothesis of this paper is: Three dimensions of psychological capital have a positive impact on the four dimensions of entrepreneurial performance of the NGRMEs. Based on this review, a theoretical framework for the paper is developed.

[Figure I near here]

\section{Descriptive Data}

The Northwest Chinese province ${ }^{1}$ of Shaan $\mathrm{Xi}$ was chosen as a study area partly because of its relatively low level of development. Its Gross Domestic Product per capita in 2018 was $\$ 9827$

\footnotetext{
${ }^{1}$ In China there are five levels of local government: provincial (which includes province, autonomous region, municipality, and special administrative region), prefecture, county, township, and village.
} 
as compared to the national average of $\$ 10,007$ (China Statistical Press, 2019). It was also partly determined by convenience to keep project costs to a minimum. Shaan Xi province consists of three prefectures: Guanzhong, Shannan and Shanbei. However, as Shanbei is relatively remote, the sampling targeted Guanzhong and Shannan. While provinces were chosen on a non-probability basis, a multistage probability sampling approach was used to select participants. This involved clustering participants by urban characteristics (town or village) and then applying a simple random sampling approach. Table I shows the breakdown of random sampling of rural entrepreneurs based in towns in the administrative areas, reflecting population size at the county level. The focus of the sampling on towns recognizes that most rural entrepreneurs are based in towns rather than villages. In total, 571 rural entrepreneurs were sampled.

[Table I near here]

The data was collected by researchers from the Business Management Research Centre of Northwest A and F University. Before the survey, a pilot study was conducted in Yuzhong County, Yongdeng County of Gansu Province and Yangling demonstration zone of Shaanxi Province. The final version of the survey questionnaire was adjusted and modified based on the outcomes of this pilot study. All researchers, who were involved in the data collection process, were trained appropriately to guarantee data validity. All the respondents were business owners who either were at the stage of business start-up or had been running their businesses for a few years. From the 571 sampled, all questionnaires were collected, but only 525 were deemed valid. Therefore, the response rate was $92 \%$. The characteristics of the respondents are summarized in the Table II, which shows that most respondents were aged between 18 to 40 years old with a relatively higher level of education (middle and high school) that would be expected of new-generation rural workers that become new entrepreneurs. 
[Table II near here]

The gender ratio of the surveyed NGRMEs was almost equally distributed, while most respondents were in the age group of 19-36 years old, with 16.7 per cent in the age group of 31-33 years old, 14.8 per cent in the age group of 34-36 years old and 14.2 per cent in the age group of 28-30 years old. The number of married respondents was 91.6 per cent of the sample, whereas most NGRMEs' education level was either junior high school (43.9 per cent) or high school (25.7 per cent). Over half (54.8 per cent) of respondents were engaged with wholesaling, retailing or processing activities, while 30.6 per cent were involved with community services, 7.8 per cent in planting and breeding activities, 0.8 per cent in E-commerce and 6.0 per cent in other activities. In terms of their business types, most were working in family-based businesses (97.5 per cent), with 1.7 per cent in a partnership and 0.8 per cent in cooperative.

\section{Variables Description and Model Construction}

\subsection{Variables description}

To identify distinct patterns of response in more detail, factor analysis was employed. This was based on responses to 5-point Likert scale questions that measured the multi-dimensional aspects of social and psychological capital, and the entrepreneurial performance of the NGRMEs. This was particularly important given the two sets of variables connected to social and psychological capital that were hypothesized to have a significant impact on entrepreneurial performance. As such, factor analysis extracted variables that described social capital and psychological capital forming a set of independent variables for the multiple regression model, whereas the extracted variables for entrepreneurial performance formed the set of dependent variables.

\subsubsection{Independent variables}


As noted, social capital and psychological capital of the NGRMEs were the independent variables. In line with Silva et al., (2007), Xu and Chen (2018), and Ke et al., (2017), social capital of the NGRMEs was measured by items such as: you have many relatives who frequently communicate with you; you get support from most of your friends when you start your business; you can easily get personal help from your relatives and friends; you are living in a village or community where the villagers have strong cohesion; and you have established close contacts with potential or existing business partners, etc. Similarly, the psychological capital of the NGRMEs was measured by items such as: you have the courage and risk-taking spirit that will help you succeed; you can maintain an optimistic mentality under any circumstances; and you are becoming more confident about the future, etc.

\subsubsection{Dependent variables}

The entrepreneurial performance of the NGRMEs were similar to those of Brettell et al. (2009). These included measures such as: your business is proceeding as planned; you have fulfilled your goal of entrepreneurship; your proposed new technologies or methods are imitated or applied; your entrepreneurship is able to motivate your relatives to get employed or start a business; and entrepreneurship makes you feel you contribute to society, etc.

The table III describes specific dimensions and variables of social capital, psychological capital and entrepreneurial performance.

[Table III near here]

\subsection{Reliability and validity test}

The analysis was conducted using SPSS20.0. Initially, the Cronbach's alpha coefficient test was used to ensure the reliability of each variable. The results in Table III show that the $\alpha$ - 
reliability coefficients of social capital variables as 0.899 , psychological capital as 0.908 , and entrepreneurial performance as 0.912 . These results, and the summated scale reliability test results, indicates that the questionnaire had a high degree of internal consistency and can be considered reliable.

To identify the underlying structural relationships between variables, factor analysis was employed and the factor score was used to select appropriate variables. To examine the appropriateness of the variables, the Kaiser-Meyer-Olkin (KMO) measure of sampling adequacy and Bartlett's test of sphericity were conducted. A KMO value of 0.5 is necessary for an adequate factor analysis to continue. The KMO statistics for social capital subscale (0.847), psychological capital subscale (0.912) and entrepreneurial performance subscale $(0.890)$ are presented in Table III. Furthermore, Bartlett's test value was 0.000 , and indicated that the data explored in this paper was appropriate for factor analysis and use in the subsequent multiple linear regression model.

[Table IV near here]

\subsection{Factor analysis}

Factor analysis evaluated the constituent dimensions for social capital, psychological capital, and entrepreneurial performance of NGRMEs. In terms of the dependent variables in the multiple regression model, factor analysis revealed four factors that corresponded to NGRMEs and their variables, indicating their entrepreneurial performance (see Table V). For instance, Factor 1 was highly related to financial performance (improved income and quality of life); Factor 2 was associated with customer performance; Factor 3 focused more on learning and growth performance; while Factor 4 reflected internal business process performance.

[Table V near here] 
Furthermore, five factors linked to social capital and its literature were extracted. Namely, social reputation, social network, social participation, social support and social trust. Table VI presents the factor scores of these measures. Factor 1 had five variables that link to social reputation - that is, the readiness of family and friends to give support. Four variables associated with Factor 2 reflected the respondents' social networks in establishing contacts and acquiring new information. Factor 3, 4 and 5 each had three variables respectively related to social participation, social support and social trust.

[Table VI near here]

Three factors were extracted from the psychological capital variables (Table VII). The seven variables associated with Factor 1 related to entrepreneurial happiness; six variables associated with Factor 2 reflected self-efficacy; and five variables relevant to Factor 3 indicated an attitude towards innovation and risk propensity.

[Table VII near here]

\subsection{Model specification}

The results of the factor analysis provided continuous variables for social capital, psychological capital and entrepreneurial performance of NGRMEs. These were used to build a multiple linear regression model in which social and psychological capital were the independent variables. The dependent variables were different aspects of entrepreneurial performance of the NGRMEs. The multiple linear regression model is specified as:

$$
Y_{I}=\beta_{0}+\sum_{i=1}^{5} \beta_{i} S C_{i}+\sum_{j=1}^{3} \beta_{j} P C_{j}+\varepsilon(I=1,2,3,4 ; i=1,2,3,4,5 ; j=1,2,3)
$$


In the model, $\mathbf{Y}_{\mathbf{I}}$ represents the entrepreneurial performance of the NGRMEs, whereas $Y_{1}$ is financial performance, $Y_{2}$ customer performance, $\mathbf{Y}_{3}$ learning and growth performance, and $\mathbf{Y}_{\mathbf{4}}$ is performance of internal business process. $\mathrm{SC}_{\mathrm{i}}$ represents dimensions of social capital, whereas $\mathrm{SC}_{1}$ is social reputation, $\mathrm{SC}_{2}$ social participation, $\mathrm{SC}_{3}$ social network, $\mathrm{SC}_{4}$ social trust and $\mathrm{SC}_{5}$ is social support. $\mathrm{PC}_{\mathrm{j}}$ represents the dimensions of psychological capital, including innovation and risk-taking tendency $\left(\mathrm{PC}_{1}\right)$, sense of self-efficacy $\left(\mathrm{PC}_{2}\right)$, entrepreneurial happiness $\left(\mathrm{PC}_{3}\right)$ and residual term $\varepsilon$.

The first step was a correlation analysis that examined the degree of linear relationships between dimensions of the NGRMEs' social capital and psychological capital against entrepreneurial performance. The second step was a multicollinearity test to explain the rationale for the regression analysis. Finally, through the F-tests and t-tests, the overall regression equation and the significance of each explanatory variable were analysed to verify the two hypotheses: various constituent dimensions of (1) social and (2) psychological capital have significant impacts on the entrepreneurial performance of the NGRMEs.

\section{Results}

\subsection{Correlation analysis}

The analysis shows that financial performance $\left(\mathrm{Y}_{1}\right)$ was positively correlated with five independent variables for social capital (social reputation, social participation, social network, social trust, and social support) and the three independent variables of psychological capital (see Table VIII). In terms of customer performance $\left(\mathrm{Y}_{2}\right)$, the five independent variables measuring dimensions of social capital were significantly and positively correlated. This dependent variable was similarly correlated with the psychological dimensions of innovation and risk-taking, self-efficacy and particularly entrepreneurial happiness (see Table IX). 
[Table VIII and IX near here]

The social dimension, social network, had the highest correlation with learning and growth performance $\left(\mathrm{Y}_{3}\right)$ at 0.403 . However, the psychological dimensions of innovation and risk taking, self-efficacy and entrepreneurial happiness were yet higher at $0.410,0.466$ and 0.631 respectively (see Table X). Finally, the correlations between social and psychological capital and internal business process $\left(\mathrm{Y}_{4}\right)$ are given in Table XI. Again, social network was the strongest positively correlated social dimension while innovation and risk taking was the strongest in the psychological domain.

[Table X and XI near here]

\subsection{Multicollinearity test}

Regression analysis presupposes there is no multicollinearity between variables. Table XII shows that the expansion factor (VIF) were less than 10, and the tolerance value is greater than 0.01, indicating no multicollinearity exists between the dimensions (Senaviratna and Cooray, 2019). Consequently, regression analysis was appropriate for this research.

[Table XII near here]

\subsection{Regression analysis}

Using the variables generated from Factor Analysis, this paper performs a multiple regression analysis to identify significant dimensions of psychological and social capital that influence the entrepreneurial performance of Chinese NGRMEs. Table XIII gives the results of the regression analysis. The regression coefficients between social participation $\left(\mathrm{X}_{2}\right)$ social network $\left(\mathrm{X}_{3}\right)$ and entrepreneurial happiness $\left(\mathrm{X}_{8}\right)$ and financial performance $\left(\mathrm{Y}_{1}\right)$ were 
respectively $0.067(p<0.05), 0.153(p<0.01)$, and $0.526(p<0.01)$. This suggest that these three variables have a significantly positive impact on financial performance of the NGRMEs.

The regression coefficients between social reputation $\left(\mathrm{X}_{1}\right)$, social participation $\left(\mathrm{X}_{2}\right)$, social network $\left(\mathrm{X}_{3}\right)$, innovation \& risk-taking tendency $\left(\mathrm{X}_{6}\right)$, entrepreneurial happiness $\left(\mathrm{X}_{8}\right)$ and customer performance $\left(\mathrm{Y}_{2}\right)$ were respectively $0.095(\mathrm{p}<0.05), 0.107(\mathrm{p}<0.01), 0.124(\mathrm{p}<0.01)$, $0.090(\mathrm{p}<0.1)$ and $0.390(\mathrm{p}<0.01)$. The results indicate that these five variables have a significantly positive impact on customer performance of the NGRMEs.

The regression coefficients between social participation $\left(\mathrm{X}_{2}\right)$, innovation and risk-taking tendency $\left(\mathrm{X}_{6}\right)$, self-efficacy $\left(\mathrm{X}_{7}\right)$, entrepreneurial happiness $\left(\mathrm{X}_{8}\right)$ and learning and growth performance $\left(\mathrm{Y}_{3}\right)$ were $0.089(\mathrm{p}<0.05), 0.097(\mathrm{p}<0.05), 0.150(\mathrm{p}<0.01)$ and $0.500(\mathrm{p}<0.05)$ respectively. Therefore, these four variables have a significantly positive impact on learning and growth performance of the NGRMEs.

The regression coefficients between social network $\left(\mathrm{X}_{3}\right)$, innovation and risk-taking tendency $\left(\mathrm{X}_{6}\right)$, entrepreneurial happiness $\left(\mathrm{X}_{8}\right)$ and the performance of the NGRMEs' internal business processes $\left(\mathrm{Y}_{4}\right)$ were respectively $0.180(\mathrm{p}<0.01), 0.231(\mathrm{p}<0.01)$ and $0.191(\mathrm{p}<0.01)$. As such, these three variables have a significantly positive impact on the performance of the NGRMEs' internal business processes.

[Table XIII near here]

\section{Discussions and Conclusions}

Previous research has studied the composition of Chinese migrant workers' social capital, psychological capital, and entrepreneurial performance (Guo and Zhou, 2013; Xu and Chen, 2018; Zhang et al., 2008; Huang and Zou, 2014). However, NGRMEs are a special group of former migrant workers, and their social capital and psychological capital differ from those of 
their older generations (Wang et al., 2011; Wu et al., 2019). This paper used factor analysis to analyse the constituent dimensions of social capital, psychological capital (independent variables) and entrepreneurial performance (dependent variable) of NGRMEs. The results reveal that the social capital of NGRMEs consists of five dimensions: social reputation, social participation, social network, social trust and social support. These findings expand Huang and Zou's (2014) study, as well as highlights the central role that social networks play in eentrepreneurial process (Ma et al., 2019). The psychological capital of NGRMEs consists of three dimensions: innovation and risk-taking tendency, self-efficacy and entrepreneurial happiness. These findings also provide support for the results of entrepreneurship literature (e.g. Luthans et al., 2007b; Ke et al., 2009; Wu et al., 2012; Lou and Ding, 2012). Similarly, it is shown that the entrepreneurial performance of NGRMEs consists of financial performance, customer performance, learning and growth performance and performance of internal business process. These results confer prior literature (e.g. Chrisman et al., 1998; Sun et al., 2010; Zhou and Xie, 2012). These results are summarized in Table XIV.

[Table XIV near here]

Using a multiple linear regression model, this research empirically shows the suggested relationships that different dimensions of social capital and psychological capital have on the following entrepreneurial performances of NGRMEs: financial, customer, learning and growth and internal business process. The results illustrate significant correlations between the dimensions of social and psychological capital with the four indicators of entrepreneurial performance. Furthermore, the various dimensions of social and psychological capital of NGRMEs have different impacts on the various dimensions of their entrepreneurial performance. That is, social and psychological capital have a positive impact on the 
entrepreneurial performance of NGRMEs with respect to various constituent dimensions resulting in differential impacts (Table XV). Hence, $\mathrm{H} 1$ and $\mathrm{H} 2$ are partially supported.

[Table XV near here]

This study confirms the findings of prior literature, such as Luthans et al., (2005); Schwarz, (2017); Zhang, (2015); and Huang et al., (2010). However, there is divergence too. Social reputation in social capital mainly refers to NGRMEs' obtaining resources such as funds and technical support from relatives and friends in the process of entrepreneurship. The more resources received, the better the social reputation. Given such resources, NGRMEs start their businesses and grow them more effectively. This suggests that social reputation may influence the customer performances of the NGRMEs but there is no significant impact on their financial performance, learning and growth performance or performance of internal business process.

Social participation mainly focuses on the cohesion and mutual aid between those villages or communities where NGRMEs had lived. Therefore, the influence of social participation on the entrepreneurship of the NGRMEs is reflected in the external environment rather than the improvement of the internal business process. Thus, social participation has no significant impact on the performance of internal business process.

Social networks refer to the provision of useful information for potential and existing customers and business partners as well as the establishment of good connections. Through actively making contact and interacting with customers, NGRMEs generate more income, expand the scale of their businesses, and most importantly, they may feel recognized by their society. However, in the short term, social networks have little impact on enhancing NGRMEs' selfworth, improving their abilities due to the lag of making contact and interacting with customers. Thus, social networks have no significant influence on learning and growth performance. 
Social trust and support mainly refer to the degree of mutual trust between NGRMEs and their family and friends, and the degree of support obtained from relatives and friends in the process of entrepreneurship. Ding and Guo (2013a) found that both social trust and social support influence the entrepreneurial performance of NGRMEs. Yet the findings of this study show that social trust and support have no substantial impact on all dimensions of entrepreneurial performance. The reason being that NGRMEs' entrepreneurial behaviour may break the tradition in terms of the production method and lifestyle pattern, which may generate certain risks. Therefore, their relatives, friends and family members may have low trust and support for their new form of entrepreneurship.

The innovative ability of NGRMEs is weaker when comparing to other groups, such as college students who have received a higher level of education (Ding and Guo, 2013a). It is thought that NGRMEs can be innovative and take risks when attempting to resolve difficulties encountered in the entrepreneurial process. The influence of innovation and risk taking tendency is reflected in the learning and growth performance and performance of internal business process. This shows that NGRMEs' abilities in developing new ideas and new methods and using new technologies is limited. Thus, innovation and risk taking has no significant impact on financial performance.

Self-efficacy refers to the determination, enthusiasm, belief and other factors contained in the psychological capital, which enable NGRMEs to go through frustrations and setbacks in the entrepreneurial process (Brändle et al., 2018). Facing higher sunk costs and opportunity costs in starting a business, NGRMEs may not be able to persist with a positive attitude, creativity and optimism unless being equipped with strong sense of self-efficacy in the entrepreneurial process (Wang and Fan 2004). Self-efficacy is reflected in learning and growth performance (Rui and Fang, 2017) but it has no significant impact on any other performance. 
Entrepreneurship happiness is the subjective perception of NGRMEs towards their current income and the business they have started (Zhang et al., 2008). NGRMEs are still characterized as content with settling for less. This is in line with the findings of Xie et al. (2016) that most of NGRMEs will have a sense of accomplishment and happiness when they achieve some results in the entrepreneurial process. Hence, entrepreneurship happiness has a significant positive correlation with the various dimensions of entrepreneurial performance exhibited by NGRMEs. Ultimately, entrepreneurship happiness may help to generate better entrepreneurial performance.

\section{Implications}

This research has both theoretical and practical implications. Previous research on factors that influence NGRMEs' entrepreneurial performance have mainly focused on individual and family endowment, environmental perception, opportunity identification, and social capital (Ding and Guo, 2013b; Zhang, 2013; Luo and Chen, 2015; Zhang et al., 2015a; Zhao, 2016; Wang and Sun, 2018). However, the impact of psychological capital on entrepreneurial performance has been neglected. Barney (1991) highlighted that the creativity, entrepreneurial spirit, resources and its allocation and development are the keys for businesses to obtain excess profits and maintain their competitive advantages. Therefore, this research paper puts forward a logical framework for the entrepreneurial performance of the NGRMEs based on the two heterogeneous resources of social capital and psychological capital. This paper expands the theoretical application in the Chinese context. In addition, this research fills the current research literature gap on NGRMEs' entrepreneurship from the perspective of psychological capital.

Existing research on NGRMEs' entrepreneurial performance are mainly focused on individual or organizational performance (Liu, 2018a), thereby lacking research on NGRMEs' performance of internal business process and learning and growth performance in their 
entrepreneurial process. Therefore, this paper fills the existing literature gap by applying a balanced scorecard theory to measure the entrepreneurial performance of NGRMEs. The paper also constructs the measurement dimensions for NGRMEs' social and psychological capital, and entrepreneurial performance. This recognizes their impact of various dimensions of social and psychological capital on the entrepreneurial performance of NGRMEs.

This research also has the following practical value. The study of the mechanisms that are influenced by social capital, psychological capital and the entrepreneurial performance of NGRMEs within China is impactful in expanding the reasons for their generally low entrepreneurial performance. Many cases of former migrant workers' entrepreneurial failure illustrate that it is not enough just to have only good social capital or psychological capital in the process of former migrant workers' entrepreneurship. When both social and psychological capital are available, NGRMEs can drive their entrepreneurial performance and grow and sustain their entrepreneurial businesses. Ke et al.'s (2010) empirical study has found that although social and especially psychological capital have a positive correlation between task and peripheral performance, the positive role of social capital has not been given due attention. As a matter of fact, various dimensions of social capital and psychological capital should be equally considered while researching NGRMEs' entrepreneurial performance.

Firstly, social participation and social networks influence various dimensions of NGRMEs' entrepreneurial performance. Therefore, NGRMEs can play an active role in welfare activities to improve their ability of social participation, laying a solid foundation for the sustained development of entrepreneurship. By doing so, they can take advantage of the positive effect of their existing family and local networks, while expanding their new social network to improve their social capital. 
Secondly, innovation and risk-taking tendencies and entrepreneurial happiness effect various dimensions of NGRMEs' entrepreneurial performance. It is important to enhance NGRMEs' innovative ability. It is suggested that NGRMEs choose projects which have moderate risks and start businesses based on local resources. In doing so, NGRMEs may recognize the risk of starting a business and be psychologically prepared to face failures. Hence, their entrepreneurial happiness can be maintained.

Thirdly, relevant government departments should strengthen policy support for business startups by NGRMEs. It is noted in the research that $82.2 \%$ of NGRMEs rarely acquire support for their business start-up by participating in cooperatives and other social groups, and $71.3 \%$ NGRMEs find it difficult to obtain business loans from banks. Apparently, it is still challenging for NGRMEs to access social and financial support for their business start-up. Thus, it is pertinent that the government focuses policy support on the social and financial aspects of entrepreneurship. For example, extending the innovative "government + bank + insurance" financing model (Xinhuanet, 2018) to support the business activities of NGRMEs so that their financing bottleneck issues can be resolved. In addition, government at all levels should regularly organize entrepreneurship training, entrepreneurship exchange meetings, etc., to encourage the NGRMEs to actively share and exchange knowledge and experiences so that NGRMEs can improve their problem resolving abilities and enhance their self-efficacy. Similarly, local governments or town committees at all levels should stimulate NGRMEs' passion for adventure and innovation by identifying and rewarding local star entrepreneurs. This would inspire them to achieve better entrepreneurial performance and to motivate them to share their experiences with other newer NGRME entrepreneurs.

\section{Research Limitations}


There are still some shortcomings in this research that need to be further explored. The research object of this study is the new generation of migrant workers that became new entrepreneurs. It explores the relationship between their social and psychological capital against their entrepreneurial performance. However, social and psychological capital of NGRMEs in different groups are not necessarily the same and their impact on entrepreneurial performance will differ. Future research may therefore explore relationships between different generations of male and female new-generation migrant entrepreneurs or that between new farmers and rural entrepreneurs. This would enable more targeted policy recommendations focused on encouraging entrepreneurs to contribute to rural and regional development by improving the performance of different subsets of NGRMEs as well as guiding their entrepreneurial practices.

In addition, this study focuses on empirical analysis, but entrepreneurial performance of NGRMEs is a complex process, and empirical analysis does not fully reveal the essential characteristics of entrepreneurship. Therefore, future research should consider introducing case studies to complement empirical research.

Finally, due to the limitation of the research location, the data used in the paper only represents the situation of Shaanxi Province, and therefore has certain geographical restrictions. This limits its application to other regions. 


\section{References}

Aldrich, H. E., and Zimmer, C. (1986), "Entrepreneurship through Social Networks", California Management Review, Vol.33, pp. 3-23.

and Sons.

Avey, J. B., Patera, J. L. and West, B. J. (2006), “The implications of positive psychological capital on employee absenteeism", Journal of Leadership and Organizational Studies, Vol.13 No.2, pp. 42-60.

Avey, J.B., Luthans, F., Smith, R.M., and Palmer, N.F. (2010), "Impact of Positive Psychological Capital on Employee Well-Being Over Time”, Journal of Occupational Health Psychology, Vol.15 No.1, pp. 17-28.

Avolio, B. J. (2005), “The chief integrative leader: Moving to the next economy's HR leader”. In: The Future of Human Resource Management: 64 Thought Leaders Explore the Critical Issues of Today and Tomorrow, edited by M. Losey, S. Meisinger, D. Ulrich. N.J: John Wiley $\&$ Sons.

Baker, T., \& Welter, F. (2020). “Contextualizing entrepreneurship theory”, Routledge, New York.

Baluku, M. M., Kikooma, J. F., Bantu, E., \& Otto, K. (2018). "Psychological capital and entrepreneurial outcomes: the moderating role of social competences of owners of microenterprises in East Africa", Journal of Global Entrepreneurship Research, Vol 8, pp. 1-23.

Barney, J. (1991), Firms Resources and Sustainable Competitive Advantage”, Journal of Management, Vol. 17 No.1, pp. 99-112. 
Bockorny, K. and Youssef-Morgan, C. M. (2019), “Entrepreneurs' courage, psychological capital, and life satisfaction”, Frontiers in psychology, Vol.10 No. 789, pp.1-6.

Borman, W. C. and Motowidlo, S. J. (1993), "Expanding the criterion domain to include elements of contextual performance." In Personnel Selection in Organization, edited by N. Schmitt, and W. Borman. New York: Jossey-Bass.

Bourdie, P. and Passeron, J.C. (1977), "Reproduction in education, society and culture",. British Journal of Sociology, Vol. 30 No. 2, pp. 139-156.

Brändle, L., Golla, S. and Kuckertz, A 2019), "How entrepreneurial orientation translates social identities into performance", International Journal of Entrepreneurial Behavior \& Research, Vol. 25 No. 7, pp. 1433-1451.

Brauw, A. and Rozelle, S. (2008), "Reconciling the Returns to Education in Off-Farm Wage Employment in Rural China”, Review of Development Economics, Vol.12 No.1, pp. 57-71.

Brettel, M., Engelen, A., and Heinemann, F. (2009), "New entrepreneurial ventures in a globalized world: the role of market orientation"., Journal of International Entrepreneurship, Vol. 7 No.2, pp. 80-88.

Burt, R.S. (2009), Structural Holes: The Social Structure of Competition, Harvard University Press, MA.Cao, X. and Lin, J. (2010), "Policy paper promises more efforts for rural-urban integration special report: No.1 Document targets rural-urban development", available at: http://news.xinhuanet.com/english2010/china/2010-02/01/c_13158156.html (accessed 20 Feb 2019).

Chen, M.Y., Liu, J., Ma, H.Y. and Zhang, Y. H. (2019), "Research on the impact of the new generation of migrant workers' psychological capital and entrepreneurial opportunity 
recognition on entrepreneurial performance", Journal of Sichuan University of Arts and Science, Vol. 2, pp.103-110.

Chen, Y.M. (2013), “The Influencing Factors on New-generation Rural Workers' Psychological Capital”, Journal of Urban Problems Vol. 2, pp. 63-67.

Chen, Z.J. and Hu, W. (2016), "Human capital, geographic characteristics, and the willingness of migrant workers to become urbanized-An empirical analysis based on the structural equation model”, Agricultural Technology Economy, Vol. 1, pp. 37-47.

Cheng, C. (2015), "Entrepreneurs' psychological capital and entrepreneurial performance: testing the complex model”, Science Research Management, Vol.36 No.10, pp. 85-93.

China State Council (2010), "The advice on the promotion urban-rural development and cultivating the basement of agricultural development of China", People Press, Beijing.

China Statistical Press (2019), “China Statistical Yearbook 2019”, China Statistical Press, Beijing.

Chinese National Bureau of Statistics (2009), "National Bureau of Statistics of China", available at: http://www.stats.gov.cn/english (accessed 5 May 2018).

Chrisman, J. J., Bauerschmidt, A. and Hofer, C. W. (1998), “The determinants of new venture performance: An extended model”, Entrepreneurship Theory and Practice, Vol.23, pp. 5-30.

Coleman, J.S. (1988), "Social capital in the creation of human capital", American Journal of Sociology, Vol 94, pp. 95-120.

Constant, A. and Massey, D. S. (2002), "Return migration by German guestworkers: Neoclassical versus new economic theory", International Migration, Vol. 40 No.4, pp. 5-38. 
Covin, J. G. \& Slevin, D. P. (1991), “A Conceptual model of entrepreneurship as firm behaviour", Entrepreneurship Theory and Practice, Vol. 17 No. 4, pp. 7-25.

Démurger, S. and Xu, H. (2011), "Return migrants: The rise of new entrepreneurs in rural China", World Development, Vol.39 No.10, pp. 1847-1861.

Dias, C. S., Rodrigues, R. G., \& Ferreira, J. J. (2019). "What's new in the research on agricultural entrepreneurship?”, Journal of rural studies, Vol. 65, pp. 99-115.

Ding G., and Guo H. (2013a), “The Impact of Social Capital on Farmers' Entrepreneurship Performance.” Journal of South China Agricultural University Social Science Edition, 2013, 12(2):50-57.

Ding, G.J. and Guo, H.D. (2013b), "Networking, opportunity innovativeness and farmers' entrepreneurial performance." Chinese Rural Economy 2013 (8): 78-87.

Duan, J., Yin, J., Xu, Y. and Wu, D. (2019), “Should I stay or should I go? Job demands' push and entrepreneurial resources' pull in intention", Entrepreneurship, and Regional Development, Vol.32 No. 5-6, pp.429-448.

Duan, J.Y., Xu, Y. and Tian, X.M. (2015). “Self-efficacy and Entrepreneurial Intention of New Generation Migrant Workers: impact of social model and subjective norm", Journal of Suzhou University: Philosophy and Social Science, Vol. 3, pp.111-119.

Fan, X. G. and Zhou, G. (2013), "Stratification and Residents' Social Justice View: An Investigation of Wenzhou, Zhejiang”, Observation and Thinking, Vol. 03, pp. 42-49.

Fei, X.T. (2009), "Rural China”, the press of Shanghai People's Publishing House, Shanghai. 
Gao, J. and Zhang, Y.L. (2014), "Realization of farmers' entrepreneurship value and environmental regulation: A perspective of self-resource patching theory”, Reform, Vol. 1, pp. 87-93.

Gmelch, G. (1980) “Return migration”, Annual Review of Anthropology, Vol. 9, pp. 135-159.

Gu, C., Hu, L, and Cook, I. (2017), “China's urbanization in 1949-2015: processes and driving forces", Chinese Geographical Science, Vol. 27 No. 6, pp. 847-859.

Guo, H.D. and Zhou, H.J. (2013), "Previous Experience, Entrepreneurial Alertness and Farmers' Entrepreneurial Opportunity Identification: A mediating effect model and revelation", Journal of Zhejiang University: Humanity and Social Science, Vol. 43 No. 4, pp. 17-27.

Guo, Y.N. and Yao, Y. (2013), "Clan network and rural labor mobility", Managing the world, Vol. 003, pp. 69-81.

Han, C. and Gao, S.X. (2018), "Entrepreneurial direction, entrepreneurial form and dual dimension organisational performance", Studies in Science of Science. Vol. 36 No. 1, pp. 114122.

Hao, L. (2012), “Cumulative Causation of Rural Migration and Initial Peri-Urbanization in China”, China Social Review, Vol. 44, pp. 6-33.

Hmieleski, K.M. and Carr, J.C. (2008), “The relationship between entrepreneur psychological capital and new venture performance", Frontiers of Entrepreneurship Research, Babson College Entrepreneurship Research Conference (BCERC. 2008), Babson College.

Hu, J.B. (2015), "Career Experience, Regional Environment and Rural Workers Entrepreneurial Intention after Return Hometown", Journal of Rural Economics, Vol.7, pp. 111-115. 
Huang, J. and Zou, F.F. (2014), “The effect of Returned rural entrepreneurs' entrepreneurial resources on entrepreneurial performance," Journal of Agrotechnical Economics, Vol. 4, pp. 80-88.

Huang, J., Cai, G. N. and Mai, Y.Y. (2010), "Rural Micro Enterprise: entrepreneurs' social capital and initial enterprise performance", Chinese Rural Economy, Vol. 5, pp. 65-73.

Huang, Z. H. (2011), “A survey report on Chinese migrant workers returning to their hometowns to start a business", Survey the World, Vol. 8, pp.36-39.

Jensen, S.M. and Luthans, F. (2006), "Relationship between entrepreneurs' psychological capital and their authentic leadership", Journal of Managerial Issues, Vol. 18 No. 2, pp. 254273.

Kaplan, R. S. and D.P. Norton (1992), “The Balanced Scorecard: Measures that Drive Performance", Harvard Business Review, (January-February): pp. 71-79.Ke, J.L., Sun, J.M. and Li, Y.R. (2009), "Psychological capital: Chinese indigenous scale's development and its validity comparison with the Western scale”, Acta Psyhologica Sinica, Vol. 41 No. 9, pp. 875888.

Ke, J.L., Sun, J.M., Shi, J.T. and Gu, Q.X. (2010), "The effect of human capital, social capital and psychological capital on work performance", Journal of Management Engineering, Vol. 24 No. 4, pp. 29-35.

Lenton, P. and Lu, Y. (2016), “The Educational Success of China's Young Generation of Ruralto-Urban Migrants", available at: http://eprints.whiterose.ac.uk/100867/1/paper_2016007.pdf, (accessed on 10/03/2018). 
Li, B. and Chen, J. (2016), "The media use analysis of new generation rural migrant workers adaptation to the urban society in China", In 2016 5th International Conference on Social Science, Education and Humanities Research, Atlantis Press, pp. 1206-1211.

Li, B. and Huo, S. (2016), “Analysis of social media influence on new generation rural migrant workers' continuing vocational learning", Education and Humanities Research, Vol. 65, pp. $428-431$.

Li, G. and Yan, S. (2016), "Psychological capital: origin, connotation and the related factors", Canadian Social Science, Vol. 12 No. 8, pp. 71-77.

Li, H. X. (2012), “Research on the Impact of College Students' Psychological Capital on Entrepreneurial Willingness”, Xi'an Engineering University, Xi'an.

Li, J. (2004), “Gender inequality, family planning, and maternal and child care in a rural Chinese country", Social Science and Medicine, Vol. 59 No. 4, pp. 695-708.

Li, S., Sicular, T. and Tarp, F. (2018), "Inequality in China: Development, transition, and policy”, WIDER Working Paper, (No. 2018/174). United Nations University (UNU), World Institute for Development Economics Research (WIDER).

Li, T. (2019), "The persistent-effect mechanism on the development of returning home to start a business in China from the perspective of structuration theory", Open Journal of Business and Management, Vol. 7 No. 3, pp. 1485-1493.

Liu, C. (2018a), "Returning migrants: the Chinese economy’s next great hope?” South China Morning Post, $18^{\text {th }}$ March.

Liu, X. (2013), "Research on the Relationship between Entrepreneurial Psychological Capital, Entrepreneurship Opportunity and Entrepreneurship Performance", Suzhou University. X.J., 
Lou, Y. and Ding, W.Y. (2012), "Critical factors influencing electronic commerce entrepreneurial performance”, Journal of Knowledge Economics, Vol. 3, pp.14-16.

Liu, Y. (2018b), "Introduction to land use and rural sustainability in China", Land Use Policy Vol. 74, pp. 1-4.

Liu, Y.S. and Li, Y.H. (2017), “Revitalize the world's countryside”, Nature, Vol. August 548, pp. $275-277$.

Liu, Z.Y. and Li, B. (2019), "Research on the iterative mechanism of entrepreneurial opportunities for start-ups”, Science Research, Vol. 37 No. 3, pp. 500-516.

Luo, D.X., Guan, P.L. and Zeng, F.E. (2009), "Feminine characteristics and entrepreneurial performance", Commercial Research, Vol. 11, pp. 71-75.

Luo, M.Z. and Chen, M. (2015), "Empirical analysis on the impact of personality traits on farmers' entrepreneurial performance", Journal of Huazhong Agricultural University: Social Science Edition, Vol. 2, pp. 41-48.

Luthans, F. and Ibrayeva, E. S. (2006) “Entrepreneurial self-efficacy in Central Asian transition economies: quantitative and qualitative analysis", Journal of International Business Studies, Vol. 37 No. 1, pp. 92-110.

Luthans, F. and Youssef, C. M. (2004), "Human, social, and now positive psychological capital management: investing in people for competitive advantage", Organizational Dynamics, Vol. 33 No. 2, pp.143-160.

Luthans, F. and Youssef-Morgan, C. M. (2017). "Psychological Capital: An Evidence-Based Positive Approach", Annual Review of Organizational Psychology and Organizational Behavior, Vol. 4, pp.339-366. 
Luthans, F., Avolio, B. J. and Walumbwa, F. (2005), “The psychological capital of Chinese workers: exploring the relationship with performance", Management and Organization Review, Vol. 1 No. 2, pp. 249-271.

Luthans, F., Avolio, B.J. Avey, J.B., and Norman, S.M. (2007a), "Positive psychological capital: measurement and relationship with performance and satisfaction", Personnel Psychology, Vol. 60 No. 3, pp. 541-572.

Luthans, F., Luthans, K. W. and Luthans, B. C. (2004), "Positive psychological capital: beyond human and social capital", Business Horizons, Vol. 47 No. 1, pp. 45-50.

Luthans, F., Youssef, C. M. and Avolio, B. J. (2007b), Psychological Capital: Developing the Human Competitive Edge”, Oxford University Press, Oxford.

Ma, H.Y. (2016), “Research on Social Capital, Psychological Capital and Migrant Workers' Entrepreneurship Performance”, Northeast Normal University, Jilin.

Ma, Zh. Zh., Zhu, J. W., Meng, Y. and Teng, Y. (2019),"The impact of overseas human capital and social ties on Chinese returnee entrepreneurs' venture performance", International Journal of Entrepreneurial Behavior \& Research, Vol. 25 No. 1, pp. 67-83.

Munshi, K. (2004), "Social learning in a heterogeneous population: technology diffusion in the Indian green revolution”, Journal of Development Economics, Vol. 73 No. 1, pp. 185-213.

Murphy, R. (2002), "How Migrant Labor is Changing Rural China”, Cambridge University Press, Cambridge. 
Narayan, D. and Cassidy, M. F. (2001), “A dimensional approach to measuring social capital: development and validation of a social capital inventory", Current Sociology, Vol. 49, pp. 59102.

Obschonka, M. (2017), , "The Quest for the Entrepreneurial Culture : Psychological Big

Data in Entrepreneurship Research", Current Opinion in Behavioral Sciences, Vol. 18, pp. $69-74$

Pei, Z.J. (2010), “Social Network and Economic Development”, Zhejiang University, Zhejiang.

Penrose, E. T. (1959), “The Theory of the Growth of the Firm (1995 ed.)”. New York: John Wiley

Portes, A. (1998), "Social capital: Its origins and applications in modern sociology", Annual Review of Sociology, Vol. 24, pp. 1-24.

Putnam, R. D. (2000), “Bowling alone: The collapse and revival of American community”, Simon and Schuster, New York.

Qi, W., Deng, Y. and Fu, B. (2019), "Rural attraction: the spatial pattern and driving factors of China's rural in-migration," Journal of Rural Studies (in press).

Ren, H., Wen, Z.L. and Chen, Q.S. (2013), "The influence of psychological capital on organisational employees career success: the medium effect of occupational commitment", Journal of Psychological Science, Vol. 4, pp. 960-964.

Rui, Z.Y. and Fang, C.L. (2017), “Research on the impact mechanism of the entrepreneurial resilience of the new generation of migrant workers - Based on the perspective of the 
difference in the role of the entrepreneurial capital dimension", Social Science, Vol. 5, pp. 5460.

Sabatini, F. (2009), "Social capital as social networks: A new framework for measurement and an empirical analysis of its determinants and consequences", The Journal of Socio-Economics, Vol. 38 No. 3, pp. 429-442.

Şahin, F., Karadağ, H. and Tuncer, B. (2019), "Big five personality traits, entrepreneurial selfefficacy and entrepreneurial intention”, International Journal of Entrepreneurial Behavior \& Research, Vol. 25 No.6, pp. 1355-2554.

Schwarz, S. (2017), “The Role of Human Capital, Social Capital, and Psychological Capital in Micro-Entrepreneurship in China", $\mathrm{PhD}$ dissertation, University of Nottingham, Nottingham.

Seligman, M. E. and Schulman, P. (1986), "Explanatory style as a predictor of productivity and quitting among life insurance sales agents", Journal of Personality and Social Psychology, Vol. 50 No. 4, pp. 832-838.

Senaviratna, N. and Cooray, T. (2019). "Diagnosing multicollinearity of logistic regression model”,. Asian Journal of Probability and Statistics, Vol. 5 No. 2, pp. 1-9.

Senjem, J. C. and Reed, K. (2002), "Social capital and network entrepreneurs", Frontiers of Entrepreneurship Research. Proceedings of the Babson-Kauffman Entrepreneurship Research Conference. Wellesley, MA: Arthur M. Blank Center for Entrepreneurship, Babson College.

Silva, M. J. de., Huttly, S. R. and Harpham, T. (2007), "Social capital and mental health: A comparative analysis of four low income countries", Social Science and Medicine, Vol. 64 No. 1, pp. 5-20. 
Simmons, A. B. and Cardona, R. (1972), "Rural-urban migration: who comes, who stays, who returns? The case of Bogota, Colombia, 1929-1968”, International Migration Review, Vol. 6 No. 2, pp. 166-181.

Stajkovic, A. D. and Luthans, F. (1998), "Social cognitive theory and self-efficacy: Going beyond traditional motivational and behavioural approaches", Organizational Dynamics, Vol. 26 No. 4, pp. 62-74.

Stajkovic, A. D. and Luthans, F. (2003), "Behavioral management and task performance in organizations: conceptual background, meta-analysis, and test of alternative models", Personnel Psychology, Vol. 56 No. 1, pp. 155-194.

Sun, H.X., Sun, L. and Li, M.Q. (2010), “A study of rural workers' entrepreneurship and its theoretical framework construction at transitional period", China. Foreign Economics and Management, Vol. 6, pp. 31-37.

Tang, S. and Hao, P. (2019), “The return intentions of China's rural migrants: A study of Nanjing and Suzhou", Journal of Urban Affairs, Vol. 41 No. 3, pp. 354-371.

Taormina, R.J. and Kin - Mei Lao, S. (2007), "Measuring Chinese entrepreneurial motivation: Personality and environmental influences", International Journal of Entrepreneurial Behavior \& Research, Vol. 13 No. 4, pp. 200-221. https://doi.org/10.1108/13552550710759997

Walumbwa F.O., Peterson S.J., Avolio B.J. and Hartnell C.A. (2010), “An investigation of the relationships among leader and follower psychological capital, service climate, and job performance", Personnel Psychology, Vol. 63, pp. 937-963.

Wang, C.G. (2000), "New-generation migrant rural workers' thirst for the basic citizenship", Journal of Democracy and Science, Vol. 1, pp. 18-20. 
Wang, C.M. and Fan, W. (2004), “A study of influencing factors on entrepreneurial tendency”, Journal of Psychological Sciences, Vol. 27 No. 5, pp. 1087-1090.

Wang, G.M., Li, J.X. and Zheng, Q.Q. (2011), "The effect of social network characteristics, job search strategies on the new-generation rural workers' reemployment", Issues in Agricultural Economy, Vol. 10, pp. 76-82.

Wang, H. and Zhuo, Y. (2018), “The necessary way for the development of China's rural areas in the new era-rural revitalization strategy", Open Journal of Social Sciences, Vol. 6 No. 6, pp. 97-106.

Wang, J.Q. and Sun, Z.H. (2018), “Three-dimensional capital of new agricultural entrepreneurial talents, entrepreneurial environment and entrepreneurial enterprise performance", China Rural Economy, Vol. 2, pp. 81-94.

Wang, S.G., Liu, X.L., Shi, S.J. and Ying, X.W. (2010), “The effect of human capital and social capital on returned rural workers' entrepreneurship", Issues in Agricultural Economy, Vol. 12, pp. $4-10$.

Wei, Y. (2018), "Leaving children behind: a win-win household strategy or a path to pauperization”, Eurasian Geography and Economics, Vol. 59 No. 2, pp. 164-183.

Weng, Z.L., Zhang, M.L, and Liu, X.Y. (2019), "The influencing mechanisms of entrepreneurial support for the rural students' entrepreneurial intention", Journal of Hunan Agricultural University, Vol. 20 No. 1, pp. 82-88.

Woodward, W. J. (1988), “A Social Network Theory of Entrepreneurship: An Empirical Study”, PhD dissertation, University of North Carolina. 
Wu, B., Liu, L. and Carter, C.J. (2019), "Bridging social capital as a resource for rural revitalisation in China? A survey of community connection of university students with home villages", Journal of Rural Studies (in press).

Wu, W.J., Liu, Y. and Lu, H. (2012), “The Chinese Indigenous psychological capital and wellbeing”, Acta Psychologica Sinica, Vol. 44 No. 10, pp. 1349-1370.

Xiao, W. and Li, L.Y. (2010), "Preliminary compilation of questionnaire for university students' psychological capital”, Chinese Journal of Clinical Psychology, Vol. 18 No. 6, pp. 691-694.

Xie, Y.P., Chen, X.Y. and Ye, D.R. (2016), "Does entrepreneurial passion contribute to entrepreneurial success"? Management Review, Vol.11, pp. 171-181.

Xinhuanet (2018), “The State Council Support for Rural Migrant Entrepreneurship”, available at: http://cx.xinhuanet.com/2018-01/19/c_136907311.htm, (accessed on 10/10/2020).

$\mathrm{Xu}$, J.S. and Chen, S. (2018), “The cross-hierarchy influence of group resources on individual knowledge sharing: the perspective of psychological capital", Scientific Research Management, Vol. 39 No. 3, pp. 101-109.

Yang, W.B. (2011), "Rural farmers family entrepreneurial environment, entrepreneurial activities and entrepreneurial performance", Journal of Shaoxing University of Arts and Sciences, Vol. 8, pp. 13-18.

Yang, X.P. (2012), “Influencing Factors on Entrepreneurial Performance of Rural Workers after Return to Hometown”, Jiangxi Agricultural University, Nanchang.

Yuan, F., Ye, B. and Shi, Q.H. (2019), "Chinese peasant entrepreneurship and rural multidimensional poverty reduction: A discussion based on the target-oriented 
multidimensional poverty model", Agricultural Technology and Economy, Vol. 285 No. 1, pp. 71-87.

Zhang, G.S., Sun, X. T. and Qi, D.M. (2015c), "Impact of social capital on migrant workers' choice of employment place", Journal of Agricultural and Forestry Economic Management, Vol. 14 No. 5, pp. 84-114.

Zhang, K.H. and Song, S. (2003), "Rural-urban migration and urbanization in China: evidence from time-series and cross-section analysis", China Economic Review, Vol.14, pp. 86-400.

Zhang, P., Deng, R., and Zhang, L.K. (2015b), "Entrepreneurial social capital and entrepreneurial performance", Journal of Scientific Research Management, Vol. 36 No. 8, pp. $120-128$.

Zhang, X.E., Zhang, M. Q and Wang, L.Y. (2015a), "Research on the influence mechanism of social networks on the pioneering intention of new generation migrant workers", East China Economic Management, Vol. 6, pp. 16-22.

Zhang, Y. L. (2013), "Research on the factors affecting farmers' entrepreneurship performance-based on a survey of 284 entrepreneurship farmers in Eastern China", Journal of Huazhong Agricultural University Social Science Edition, Vol. 4, pp. 19-24.

Zhang, Y. L. (2015), "Entrepreneurial environment and entrepreneurial intention of land-lost farmers during urbanization process", Northwest Population Journal, Vol. 5, pp. 49-52.

Zhang, Y.L., Yang, J. and Ren, B. (2008), "Social capital, previous experience and entrepreneurial opportunity: an interaction model and revelation", Management World Journal, Vol. 7, pp. 91-102. 
Zhao, D. Z. (2016), “A study on the factors affecting the performance of migrant workers' return to hometown”, Economist, Vol. 7 No. 7, pp. 84-91.

Zhao, L., Liu, S. and Zhang, W. (2018), "New trends in internal migration in China: profiles of the new-generation migrants", China, and World Economy, Vol. 26 No. 1, pp. 18-41.

Zhong, W.D. and Huang, Z.X. (2012),. “An empirical study on the relationship between relationship strength, self-efficacy and entrepreneurial performance”., China Science and Technology Forum, Vol. 000(001), pp.131-137.

Zhou, H.X., Ye, J.Y. and Cao, H.P. (2013), “Migrant rural workers' social capital measurement and distribution", Journal of Yunnan University of Finance and Economics, Vol. 3, pp. 141151.

Zhou, J.H. (2013), “Analysis of influencing factors of farmers' entrepreneurial performance”, Journal of Jiangxi University of Finance and Economics, Vol. 3, pp. 77-84,

Zhou, J.H. and Xie, Z. (2012), "Rural workers' entrepreneurial ability and entrepreneurial performance", Journal of Agrotechnical Economics, Vol. 5, p. 15.

Zhou, Y., Li, Y. and Xu, C. (2020), "Land consolidation and rural revitalization in China: mechanisms and paths", Land Use Policy, Vol. 91, pp. 1-13.

Zhu, M.F. (2010), “Influencing factors of rural farmers' entrepreneurial behaviour”, Journal of Rural Economics of China, Vol. 3, pp. 25-34.

Zhuang, J.C., Yin, J.C., and Wang, C.Y. (2015), "Research on the network channels and differences of migrant workers' entrepreneurship resources acquisition”, Soft Science, Vol. 29 No. 5, pp.140-144. 
Zou, F.F. and Huang, J. (2014), “The influence of entrepreneurial resources on entrepreneurial performance of rural entrepreneurs after return hometown", Journal of Agricultural Technology and Economics, Vol. 4, pp. 80-88. 


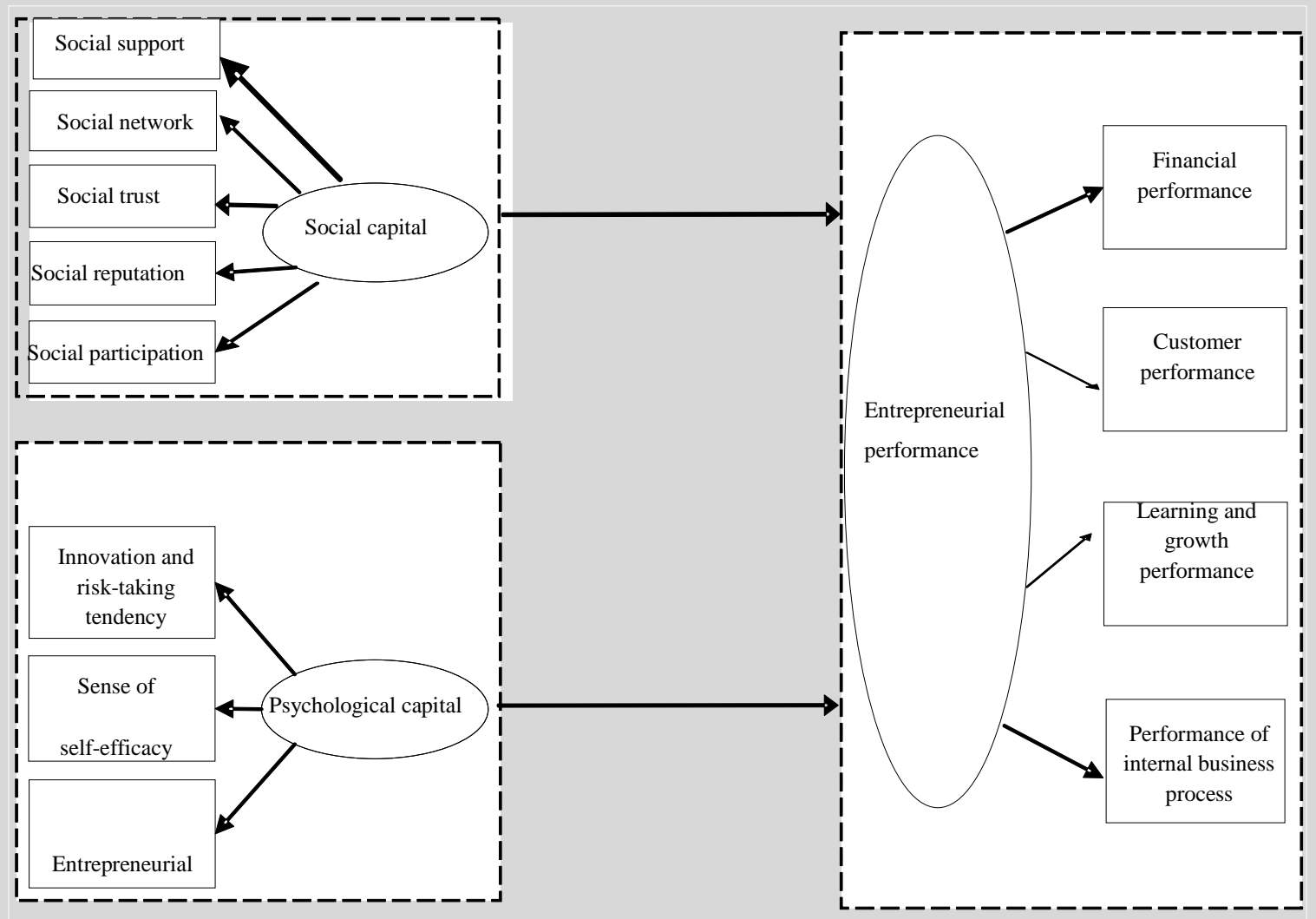

Figure I Theoretical Framework

Table I. Distribution of research samples

\begin{tabular}{|c|c|c|c|c|}
\hline City & District (County) & Township (Town) & Sample number & In total \\
\hline \multirow[t]{3}{*}{ Ankang } & Shiquan & Chihe & 125 & \multirow{3}{*}{214} \\
\hline & & Raofeng & 46 & \\
\hline & & Yinlong & 43 & \\
\hline \multirow[t]{2}{*}{ Tongchuan } & Wangyi & Wangyi & 42 & \multirow[b]{2}{*}{91} \\
\hline & & Huangbao & 49 & \\
\hline
\end{tabular}




\begin{tabular}{ccccc} 
& Linwei & Xiaji & 73 & \\
& Chongning & 46 & 266 \\
& Xinshi & 47 & \\
& Jingkai & Fengyuan & 53 & 571 \\
\hline In total & 5 & 10 & 571 & \\
\hline
\end{tabular}

Table II. Characteristics of NGRMEs $(n=525)$

\begin{tabular}{|c|c|c|}
\hline Characteristics & Item & Percentage $(\%)$ \\
\hline \multirow[t]{2}{*}{ Gender } & Male & 49.9 \\
\hline & Female & 50.1 \\
\hline \multirow[t]{10}{*}{ Age } & 16 below & 0 \\
\hline & [16-18] & 3 \\
\hline & [19-21] & 11.6 \\
\hline & [22-24] & 12.3 \\
\hline & [25-27] & 11.8 \\
\hline & {$[28-30]$} & 14.2 \\
\hline & [31-33] & 16.7 \\
\hline & {$[34-36]$} & 14.8 \\
\hline & [37-39] & 8.2 \\
\hline & 39 above & 7.4 \\
\hline \multirow[t]{4}{*}{ Marriage } & Unmarried & 7.2 \\
\hline & Married & 91.6 \\
\hline & Divorced & 0.2 \\
\hline & Widowed & 1 \\
\hline \multirow[t]{6}{*}{ Education Background } & No schooling & 5.3 \\
\hline & Primary school & 16 \\
\hline & Middle school & 43.9 \\
\hline & High school & 25.7 \\
\hline & Vocational college & 3.8 \\
\hline & Bachelor and above & 5.3 \\
\hline \multirow[t]{5}{*}{ Business activity } & Planting and breeding & 7.8 \\
\hline & Community services & 30.6 \\
\hline & $\begin{array}{l}\text { Wholesaling, retailing and } \\
\text { processing }\end{array}$ & 54.8 \\
\hline & E-commerce & 0.8 \\
\hline & Others & 6.0 \\
\hline \multirow[t]{3}{*}{ Entrepreneurial organization } & Family business & 97.5 \\
\hline & Partnership & 1.7 \\
\hline & Cooperative & 0.8 \\
\hline
\end{tabular}


Table III. Dimensions and variables descriptions

\begin{tabular}{|c|c|c|c|}
\hline Dimensions & Variables & Mean & Standard deviation \\
\hline \multirow{16}{*}{$\begin{array}{l}\text { Entrepreneurial } \\
\text { performance }\end{array}$} & Improved income & 3.83 & 0.819 \\
\hline & Better quality of life & 2.75 & 0.933 \\
\hline & Achieved entrepreneurial goal & 2.74 & 0.913 \\
\hline & Improved family life & 2.97 & 0.908 \\
\hline & Some success in present career & 2.90 & 0.966 \\
\hline & Business profitability & 3.06 & 0.946 \\
\hline & Rapid business expansion & 3.20 & 0.839 \\
\hline & Business is in good condition & 3.48 & 0.811 \\
\hline & Growth in market share & 3.47 & 0.851 \\
\hline & Achieve life values from entrepreneurship & 3.53 & 0.874 \\
\hline & Feel contributed to the society & 3.85 & 0.771 \\
\hline & Improved personal skills & 3.01 & 1.028 \\
\hline & $\begin{array}{l}\text { Allowed relatives \& friends to find employed or } \\
\text { start a business }\end{array}$ & 3.55 & 0.923 \\
\hline & Affirmation of technologies used & 3.39 & 0.835 \\
\hline & Application of technologies used & 3.21 & 0.907 \\
\hline & $\begin{array}{l}\text { Generating new ideas about production, sales, } \\
\text { management }\end{array}$ & 3.43 & 0.831 \\
\hline \multirow{7}{*}{ Social capital } & $\begin{array}{l}\text { Ability to borrow money from your relatives and } \\
\text { friends }\end{array}$ & 3.41 & 0.975 \\
\hline & $\begin{array}{l}\text { Ability to get resources from your relatives and } \\
\text { friends }\end{array}$ & 3.54 & 0.98 \\
\hline & $\begin{array}{l}\text { Ability to get physical resources from your } \\
\text { relatives and friends }\end{array}$ & 3.40 & 0.953 \\
\hline & $\begin{array}{l}\text { Ability to get informational help from your } \\
\text { relatives and friends }\end{array}$ & 3.50 & 0.995 \\
\hline & $\begin{array}{l}\text { Ability to get technical guidance from your } \\
\text { relatives and friends }\end{array}$ & 4.20 & 0.724 \\
\hline & $\begin{array}{l}\text { Acquire valuable information for your potential or } \\
\text { existing clients }\end{array}$ & 3.96 & 0.783 \\
\hline & $\begin{array}{l}\text { Establish close contact with your potential or } \\
\text { existing clients }\end{array}$ & 3.89 & 0.777 \\
\hline
\end{tabular}


existing business partners

Your village or community has got strong social

of your friends

Have a sense of belonging from your

Overall, you feel happy

Cope with unpleasant things placidly

Optimistic at any situation

Face difficulty and frustration with calmness till you have sorted it out wisely 
Brave, and you will put your ideas into action

Brave and risk taking, which helps you to get

success

Do not like sticking to the old rules but breaking

the current situation

Try adventurous plan when facing with difficulties

Not afraid of adventures

\section{Table IV. Fitness of data}

\begin{tabular}{lccc}
\hline Name & $\alpha$ reliability coefficient & KMO value & Bartlett Sphericity test sig \\
\hline Social capital & 0.899 & 0.847 & 0.000 \\
Psychological capital & 0.908 & 0.912 & 0.000 \\
Entrepreneurial performance & & 0.890 & 0.000 \\
& 0.912 & 0.915 & 0.000 \\
Summated Scale & & 0.955 & \\
\hline
\end{tabular}

Table V. Composition of entrepreneurial performance factors of NGRMEs 


\begin{tabular}{|c|c|c|c|c|c|}
\hline Financial & Improved income & 0.771 & 0.317 & 0.102 & 0.093 \\
\hline \multirow[t]{4}{*}{ performance } & Better quality of life & 0.730 & 0.354 & 0.054 & 0.086 \\
\hline & Achieved entrepreneurial goal & 0.646 & 0.417 & 0.083 & 0.156 \\
\hline & Improved family life & 0.581 & 0.012 & 0.347 & 0.127 \\
\hline & Some success in present career & 0.523 & 0.311 & 0.276 & 0.230 \\
\hline \multirow{4}{*}{$\begin{array}{l}\text { Customer } \\
\text { performance }\end{array}$} & Business profitability & 0.299 & 0.788 & 0.166 & 0.071 \\
\hline & Rapid business expansion & 0.265 & 0.717 & 0.067 & 0.240 \\
\hline & Business is in good condition & 0.242 & 0.773 & 0.158 & 0.074 \\
\hline & Growth in market share & 0.220 & 0.696 & 0.057 & 0.299 \\
\hline \multirow{4}{*}{$\begin{array}{l}\text { Learning } \\
\text { growth } \\
\text { performance }\end{array}$} & Achieve life values from entrepreneurship & 0.373 & 0.079 & 0.705 & 0.181 \\
\hline & Feel contributed to the society & 0.121 & 0.169 & 0.752 & 0.109 \\
\hline & Improved personal skills & 0.459 & -0.056 & 0.655 & 0.101 \\
\hline & $\begin{array}{l}\text { Allowed relatives \& friends to find employed or start a } \\
\text { business }\end{array}$ & -0.242 & 0.311 & 0.681 & 0.165 \\
\hline \multirow{3}{*}{$\begin{array}{l}\text { Performance of } \\
\text { internal business }\end{array}$} & Affirmation of technologies used & 0.138 & 0.138 & 0.083 & 0.915 \\
\hline & Application of technologies used & 0.111 & 0.163 & 0.180 & 0.889 \\
\hline & Generating new ideas about production, sales, management & 0.187 & 0.249 & 0.237 & 0.580 \\
\hline
\end{tabular}


Table VI. Factor analysis of the social capital variables

\begin{tabular}{|c|c|c|c|c|c|c|}
\hline \multirow[t]{2}{*}{ Dimensions } & \multirow[t]{2}{*}{ Variables } & \multicolumn{5}{|c|}{ Factors } \\
\hline & & 1 & 2 & 3 & 4 & 5 \\
\hline \multirow{5}{*}{ Social reputation } & Ability to borrow money from your relatives and friends & 0.772 & 0.082 & 0.054 & -0.024 & 0.257 \\
\hline & Ability to get resources from your relatives and friends & 0.865 & 0.084 & 0.088 & 0.062 & 0.195 \\
\hline & Ability to get physical resources from your relatives and friends & 0.812 & 0.137 & 0.057 & 0.168 & 0.136 \\
\hline & Ability to get informational help from your relatives and friends & 0.771 & 0.161 & 0.108 & 0.291 & -0.071 \\
\hline & Ability to get technical guidance from your relatives and friends & 0.717 & 0.137 & 0.157 & 0.298 & -0.105 \\
\hline \multirow{5}{*}{ Social network } & Acquire valuable information for your potential or existing clients & 0.152 & 0.769 & 0.119 & 0.277 & -0.083 \\
\hline & Establish close contact with your potential or existing clients & 0.095 & 0.862 & 0.034 & 0.110 & 0.081 \\
\hline & & & & & & \\
\hline & Acquire valuable information from your potential or existing business partners & 0.160 & 0.815 & 0.141 & 0.209 & 0.059 \\
\hline & Establish close contact with your potential or existing business partners & 0.189 & 0.704 & 0.158 & -0.009 & 0.231 \\
\hline \multirow{3}{*}{ Social participation } & Your village or community tend to be good at solving problems jointly & 0.152 & 0.045 & 0.884 & 0.074 & 0.110 \\
\hline & Your village or community tend to help each other & 0.097 & 0.099 & 0.926 & 0.082 & 0.093 \\
\hline & Your village or community has got strong social cohesion & 0.107 & 0.122 & 0.913 & 0.095 & 0.134 \\
\hline \multirow{3}{*}{ Social support } & Your start-up has obtained support from the majority of your families & 0.053 & 0.124 & 0.174 & 0.712 & 0.358 \\
\hline & Your start-up has obtained support from the majority of your relatives & 0.292 & 0.180 & 0.049 & 0.797 & 0.223 \\
\hline & Your start-up has obtained support of the majority of your friends & 0.295 & 0.163 & 0.058 & 0.757 & 0.170 \\
\hline Social trust & Mutual trust exists between you and your family & 0.071 & 0.161 & 0.257 & 0.198 & 0.773 \\
\hline
\end{tabular}


Table VII. Factor analysis of the psychological capital variables

\begin{tabular}{|c|c|c|c|c|}
\hline \multirow[t]{2}{*}{ Dimensions } & \multirow[t]{2}{*}{ Variables } & \multicolumn{3}{|c|}{ Factors } \\
\hline & & 1 & 2 & 3 \\
\hline \multirow{7}{*}{ Innovation and risk-taking } & Very satisfied with your life & 0.824 & 0.123 & 0.035 \\
\hline & Have a sense of belonging from your entrepreneurial activities & 0.762 & 0.160 & 0.139 \\
\hline & Enjoy the current situation of pursuing your career & 0.748 & 0.156 & 0.164 \\
\hline & Enjoy your life when you are not working & 0.734 & 0.176 & 0.126 \\
\hline & Satisfied with your current entrepreneurial income & 0.697 & 0.039 & 0.121 \\
\hline & Start-up business makes you feel confident in future & 0.675 & 0.170 & 0.230 \\
\hline & Overall, you feel happy & 0.658 & 0.203 & -0.015 \\
\hline \multirow{7}{*}{ Self-efficacy } & Cope with unpleasant things placidly & 0.192 & 0.803 & 0.083 \\
\hline & Optimistic at any situation & 0.217 & 0.786 & 0.105 \\
\hline & Face difficulty and frustration with calmness till you have sorted it out & 0140 & 775 & 0246 \\
\hline & wisely & 0.149 & $0 . / 15$ & 0.240 \\
\hline & Cope effectively with any things unexpected & 0.176 & 0.705 & 0.307 \\
\hline & Persist in achieving your target even though you are down in spirits & 0.113 & 0.703 & 0.380 \\
\hline & Maintain your persistence for quite a while till you hit your target & 0.259 & 0.587 & 0.390 \\
\hline \multirow{5}{*}{ Entrepreneurial happiness } & Brave, and you will put your ideas into action & 0.174 & 0.150 & 0.839 \\
\hline & Brave and risk taking, which helps you to get success & 0.098 & 0.168 & 0.836 \\
\hline & Do not like sticking to the old rules but breaking the current situation & 0.108 & 0.147 & 0.835 \\
\hline & Try adventurous plan when facing with difficulties & 0.165 & 0.377 & 0.664 \\
\hline & Not afraid of adventures & 0.053 & 0.272 & 0.533 \\
\hline
\end{tabular}

Table VIII. Matrix of correlation coefficient between social capital and psychological capital and financial performance

\begin{tabular}{|c|c|c|c|c|c|c|c|c|c|}
\hline Variable & $\mathrm{Y}_{1}$ & $\mathrm{X}_{1}$ & $\mathrm{X}_{2}$ & $\mathrm{X}_{3}$ & $\mathrm{X}_{4}$ & $\mathrm{X}_{5}$ & $\mathrm{X}_{6}$ & $\mathrm{X}_{7}$ & $\mathrm{X}_{8}$ \\
\hline Financial performance $\left(\mathrm{Y}_{1}\right)$ & 1 & & & & & & & & \\
\hline Social reputation $\left(\mathrm{X}_{1}\right)$ & $0.291^{* *}$ & 1 & & & & & & & \\
\hline Social participation $\left(\mathrm{X}_{2}\right)$ & $0.270^{* *}$ & $0.298^{* *}$ & 1 & & & & & & \\
\hline Social network $\left(\mathrm{X}_{3}\right)$ & $0.455^{* *}$ & $0.366^{* *}$ & $0.270^{* *}$ & 1 & & & & & \\
\hline Social trust $\left(\mathrm{X}_{4}\right)$ & $0.362^{* *}$ & $0.378^{* *}$ & $0.337^{* *}$ & $0.384^{* *}$ & 1 & & & & \\
\hline Social support $\left(\mathrm{X}_{5}\right)$ & $0.332^{* *}$ & $0.511^{* *}$ & $0.284^{* *}$ & $0.404^{* *}$ & $0.587^{* *}$ & 1 & & & \\
\hline
\end{tabular}




\begin{tabular}{|c|c|c|c|c|c|c|c|c|}
\hline Innovation \& Risk-taking $\left(\mathrm{X}_{6}\right)$ & $0.351^{* *}$ & $0.334^{* *}$ & $0.243^{* *}$ & $0.472^{* *}$ & $0.316^{* *}$ & $0.308^{* *}$ & 1 & \\
\hline Self-efficacy $\left(\mathrm{X}_{7}\right)$ & $0.422^{* *}$ & $0.241^{* *}$ & $0.230^{* *}$ & $0.461^{* *}$ & $0.372^{* *}$ & $0.342^{* *}$ & $0.600^{* *}$ & 1 \\
\hline Entrepreneurial happiness $\left(\mathrm{X}_{8}\right)$ & $0.658^{* *}$ & $0.261^{* *}$ & $0.249^{* *}$ & $0.410^{* *}$ & $0.383^{* *}$ & $0.303^{* *}$ & $0.346^{* *}$ & $0.445^{* *}$ \\
\hline
\end{tabular}

Note:* significantly correlated at 0.05 level (bilateral), $* *$ significantly correlated at 0.01 level (bilateral)

Table IX. Matrix of correlation coefficient between social capital and psychological capital and customer performance

\begin{tabular}{|c|c|c|c|c|c|c|c|c|c|}
\hline Variable & $\mathrm{Y}_{2}$ & $\mathrm{X}_{1}$ & $\mathrm{X}_{2}$ & $\mathrm{X}_{3}$ & $\mathrm{X}_{4}$ & $\mathrm{X}_{5}$ & $\mathrm{X}_{6}$ & $\mathrm{X}_{7}$ & $\mathrm{X}_{8}$ \\
\hline Customer performance $\left(\mathrm{Y}_{2}\right)$ & 1 & & & & & & & & \\
\hline Social reputation $\left(\mathrm{X}_{1}\right)$ & $0.292^{* *}$ & 1 & & & & & & & \\
\hline Social participation $\left(\mathrm{X}_{2}\right)$ & $0.256^{* *}$ & $0.298^{* *}$ & 1 & & & & & & \\
\hline Social network $\left(\mathrm{X}_{3}\right)$ & $0.373^{* *}$ & $0.366^{* *}$ & $0.270^{* *}$ & 1 & & & & & \\
\hline Social trust $\left(\mathrm{X}_{4}\right)$ & $0.290^{* *}$ & $0.378^{* *}$ & $0.337^{* *}$ & $0.384^{* *}$ & 1 & & & & \\
\hline Social support $\left(\mathrm{X}_{5}\right)$ & $0.250^{* *}$ & $0.511^{* *}$ & $0.284^{* *}$ & $0.404^{* *}$ & $0.587^{* *}$ & 1 & & & \\
\hline Innovation \& Risk-taking $\left(\mathrm{X}_{6}\right)$ & $0.340^{* *}$ & $0.334^{* *}$ & $0.243^{* *}$ & $0.472^{* *}$ & $0.316^{* *}$ & $0.308^{* *}$ & 1 & & \\
\hline Self-efficacy $\left(\mathrm{X}_{7}\right)$ & $0.317^{* *}$ & $0.241^{* *}$ & $0.230^{* *}$ & $0.461^{* *}$ & $0.372^{* *}$ & $0.342^{* *}$ & $0.600^{* *}$ & 1 & \\
\hline Entrepreneurial happiness $\left(\mathrm{X}_{8}\right)$ & $0.506^{* *}$ & $0.261^{* *}$ & $0.249^{* *}$ & $0.410^{* *}$ & $0.383^{* *}$ & $0.303^{* *}$ & $0.346^{* *}$ & $0.445^{* *}$ & 1 \\
\hline
\end{tabular}

Note:* significantly correlated at 0.05 level (bilateral), ** significantly correlated at 0.01 level (bilateral)

Table X. Matrix of correlation coefficient between social capital and psychological capital and learning and growth performance

\begin{tabular}{|c|c|c|c|c|c|c|c|c|c|}
\hline Variable & $\mathrm{Y}_{3}$ & $\mathrm{X}_{1}$ & $\mathrm{X}_{2}$ & $\mathrm{X}_{3}$ & $\mathrm{X}_{4}$ & $\mathrm{X}_{5}$ & $\mathrm{X}_{6}$ & $\mathrm{X}_{7}$ & $\mathrm{X}_{8}$ \\
\hline Learning and growth performance $\left(\mathrm{Y}_{3}\right)$ & 1 & & & & & & & & \\
\hline Social participation $\left(\mathrm{X}_{2}\right)$ & $0.280^{* *}$ & $0.298^{* *}$ & 1 & & & & & & \\
\hline Social network $\left(\mathrm{X}_{3}\right)$ & $0.403^{* *}$ & $0.366^{* *}$ & $0.270^{* *}$ & 1 & & & & & \\
\hline Social trust $\left(\mathrm{X}_{4}\right)$ & $0.316^{* *}$ & $0.378^{* *}$ & $0.337^{* *}$ & $0.384^{* *}$ & 1 & & & & \\
\hline Social support $\left(\mathrm{X}_{5}\right)$ & $0.253^{* *}$ & $0.511^{* *}$ & $0.284^{* *}$ & $0.404^{* *}$ & $0.587^{* *}$ & 1 & & & \\
\hline Innovation \& Risk-taking $\left(\mathrm{X}_{6}\right)$ & $0.410^{* *}$ & $0.334^{* *}$ & $0.243^{* *}$ & $0.472^{* *}$ & $0.316^{* *}$ & $0.308^{* *}$ & 1 & & \\
\hline Self-efficacy $\left(\mathrm{X}_{7}\right)$ & $0.466^{* *}$ & $0.241^{* *}$ & $0.230^{* *}$ & $0.461^{* *}$ & $0.372^{* *}$ & $0.342^{* *}$ & $0.600^{* *}$ & 1 & \\
\hline Entrepreneurial happiness $\left(\mathrm{X}_{8}\right)$ & $0.631^{* *}$ & $0.261^{* *}$ & $0.249^{* *}$ & $0.410^{* *}$ & $0.383^{* *}$ & $0.303^{* *}$ & $0.346^{* *}$ & $0.445^{* *}$ & 1 \\
\hline
\end{tabular}

Note:* significantly correlated at 0.05 level (bilateral), ** significantly correlated at 0.01 level (bilateral)

Table XI. Matrix of correlation coefficient between social capital and psychological capital and performance of internal business process

\begin{tabular}{|c|c|c|c|c|c|c|c|c|c|}
\hline Variable & $\mathrm{Y}_{4}$ & $\mathrm{X}_{1}$ & $\mathrm{X}_{2}$ & $\mathrm{X}_{3}$ & $\mathrm{X}_{4}$ & $X_{5}$ & $\mathrm{X}_{6}$ & $\mathrm{X}_{7}$ & $\mathrm{X}_{8}$ \\
\hline Performance of internal business process $\left(\mathrm{Y}_{4}\right)$ & 1 & & & & & & & & \\
\hline Social reputation $\left(\mathrm{X}_{1}\right)$ & $0.237^{* *}$ & & & & & & & & \\
\hline
\end{tabular}




\begin{tabular}{|c|c|c|c|c|c|c|c|c|c|}
\hline Social participation $\left(\mathrm{X}_{2}\right)$ & $0.189^{* *}$ & $0.298^{* *}$ & 1 & & & & & & \\
\hline Social network $\left(\mathrm{X}_{3}\right)$ & $0.410^{* *}$ & $0.366^{* *}$ & $0.270^{* *}$ & 1 & & & & & \\
\hline Social trust $\left(\mathrm{X}_{4}\right)$ & $0.291^{* *}$ & $0.378^{* *}$ & $0.337^{* *}$ & $0.384^{* *}$ & 1 & & & & \\
\hline Social support $\left(\mathrm{X}_{5}\right)$ & $0.214^{* *}$ & $0.511^{* *}$ & $0.284^{* *}$ & $0.404^{* *}$ & $0.587^{* *}$ & 1 & & & \\
\hline Innovation \& Risk-taking $\left(\mathrm{X}_{6}\right)$ & $0.457^{* *}$ & $0.334^{* *}$ & $0.243^{* *}$ & $0.472^{* *}$ & $0.316^{* *}$ & $0.308^{* *}$ & 1 & & \\
\hline Entrepreneurial happiness $\left(\mathrm{X}_{8}\right)$ & $0.394^{* *}$ & $0.261^{* *}$ & $0.249^{* *}$ & $0.410^{* *}$ & $0.383^{* *}$ & $0.303^{* *}$ & $0.346^{* *}$ & $0.445^{* *}$ & 1 \\
\hline
\end{tabular}

Note:* significantly correlated at 0.05 level (bilateral), ** significantly correlated at 0.01 level (bilateral)

Table XII. Multicollinearity test

\begin{tabular}{ccc}
\hline & Multicollinearity statistics & VIF \\
\cline { 2 - 3 } & tolerance value & 1.503 \\
Social reputation $\left(\mathrm{X}_{1}\right)$ & 0.665 & 1.213 \\
Social participation $\left(\mathrm{X}_{2}\right)$ & 0.824 & 1.675 \\
Social network $\left(\mathrm{X}_{3}\right)$ & 0.597 & 1.745 \\
Social trust $\left(\mathrm{X}_{4}\right)$ & 0.573 & 1.870 \\
Social support $\left(\mathrm{X}_{5}\right)$ & 0.535 & 1.765 \\
Innovation \& Risk-taking $\left(\mathrm{X}_{6}\right)$ & 0.567 & 1.893 \\
Self-efficacy $\left(\mathrm{X}_{7}\right)$ & 0.528 & 1.475 \\
Entrepreneurial happiness $\left(\mathrm{X}_{8}\right)$ & 0.678 & \\
\hline
\end{tabular}

Table XIII. The regression analysis results between social capital and psychological capital and entrepreneurial performance of NGRMEs

\begin{tabular}{|c|c|c|c|c|c|}
\hline & & \multicolumn{3}{|c|}{ Entrepreneurial performance of the NGRMEs } & \multirow[b]{2}{*}{$\mathrm{Y}_{4}$} \\
\hline & & $\mathrm{Y}_{1}$ & $\mathrm{Y}_{2}$ & $\mathrm{Y}_{3}$ & \\
\hline \multirow{8}{*}{ 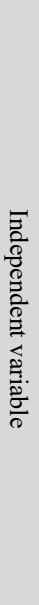 } & Social reputation $\left(\mathrm{X}_{1}\right)$ & 0.041 & $0.095 * *$ & 0.051 & 0.035 \\
\hline & Social participation $\left(\mathrm{X}_{2}\right)$ & $0.067 * *$ & $0.107 * * *$ & $0.089 * *$ & 0.009 \\
\hline & Social network $\left(\mathrm{X}_{3}\right)$ & $0.153 * * *$ & $0.124 * * *$ & 0.059 & $0.180 * * *$ \\
\hline & Social trust $\left(\mathrm{X}_{4}\right)$ & 0.009 & 0.013 & -0.007 & 0.050 \\
\hline & Social support $\left(\mathrm{X}_{5}\right)$ & 0.062 & 0.002 & -0.037 & -0.049 \\
\hline & Innovation \& risk-taking tendency $\left(\mathrm{X}_{6}\right)$ & 0.025 & $0.090 *$ & $0.097 * *$ & $0.231 * * *$ \\
\hline & Self-efficacy $\left(\mathrm{X}_{7}\right)$ & 0.052 & -0.020 & $0.150 * * *$ & 0.082 \\
\hline & Entrepreneurial happiness $\left(\mathrm{X}_{8}\right)$ & $0.526 * * *$ & $0.390 * * *$ & $0.500 * * *$ & $0.191 * * *$ \\
\hline $\begin{array}{l}3 \\
\frac{1}{0} \\
0\end{array}$ & Goodness of fit $\left(\mathrm{R}^{2}\right)$ & 0.525 & 0.348 & 0.495 & 0.304 \\
\hline
\end{tabular}




\begin{tabular}{ccccc}
\hline Adjust $\mathrm{R}^{2}$ & 0.518 & 0.338 & 0.487 & 0.294 \\
SEE & 0.477 & 0.610 & 0.490 & 0.671 \\
F test (Sig.) & 0.000 & 0.000 & 0.000 & 0.000 \\
\hline
\end{tabular}

Note: The independent variables section shows normalized regression coefficients. $* * *, * *, *$ indicate significant at the level of $1 \%, 5 \%$, and $10 \%$

Table XIV. Success Dimensions for the NGRMEs

\begin{tabular}{lll}
\hline Social Capital & Psychological Capital & Entrepreneurial Performance \\
\hline Social reputation & Innovation and risk-taking tendency & Financial performance \\
Social participation & Self-efficacy & Customer performance \\
Social network & Entrepreneurial happiness & Learning and growth performance \\
Social trust & & Performance of internal business process \\
Social support & & \\
\hline
\end{tabular}

Table XV. Hypothesis verification results

\begin{tabular}{lc}
\hline \multicolumn{1}{c}{ Hypotheses } & Result \\
\hline Social Capital (social participation, social network) $\rightarrow$ Financial performance & support \\
Social Capital (social reputation, social participation, social network) $\rightarrow$ Customer performance & support \\
Social Capital (social participation) $\rightarrow$ Learning and growth performance & support \\
Social Capital (social network) $\rightarrow$ Performance of internal business process & support \\
\hline Psychological Capital (entrepreneurial happiness) $\rightarrow$ Financial performance & support \\
Psychological Capital (innovation and risk-taking tendency, entrepreneurial happiness) $\rightarrow$ Customer performance & support \\
Psychological Capital (innovation and risk-taking tendency, self-efficacy, entrepreneurial happiness) $\rightarrow$ Learning & support \\
and growth performance & support \\
Psychological Capital (innovation and risk-taking tendency, entrepreneurial happiness) $\rightarrow$ Performance of internal & \\
business process
\end{tabular}

